\title{
Designing a model and prioritizing competencies of internal audit managers: a mixed-methods approach
}

\author{
Amin Rostami \\ Ph.D. Student in accounting, Ferdowsi University of Mashhad, Mashhad, \\ Iran, aminrostami@stu.um.ac.ir \\ Mohamad Hosein Vadeei * \\ Associate Professor, Department of Accounting, Ferdowsi University of \\ Mashhad, Mashhad, Iran. (Corresponding Author). \\ mhvadeei@um.ac.ir \\ Mohamad Ali Bagherpour Velashani \\ Associate Professor, Department of Accounting, Ferdowsi University of \\ Mashhad,Mashhad,Iran.bagherpour@um.ac.ir
}

\begin{abstract}
:
Internal auditing is an independent, objective assurance and consulting activity that helps an organization accomplish its objectives by bringing a systematic, disciplined approach to evaluate and improve the effectiveness of risk management, control and governance processes. As the roles of internal auditors increasingly change in organizations, new competencies are needed. The purpose of this research is to Identify and prioritize competencies of internal audit managers. In this research, mixed methods (quantitative and qualitative methods) are used. In other words, first, qualitative research method and grounded theory approach are used for Identifying competencies. To achieve this goal, with obtaining 18 faculty members and internal auditing experts insights through unstructured interviews in 2018-2019, we developed internal auditors' competency model in Iran. According to this model, internal auditor managers need a series of Individual, technical, managerial and environmental competencies to achieve the desired level of effectiveness. Then, in the quantitative part of the research, by analyzing the questionnaires received from internal auditors and using Friedman's test, we prioritized the dimensions of competence of internal audit managers in the small, medium and large companies of Iran. The research results show that three dimensions of work experience, academic education, and Mastery of Internal Audit Standards in small, medium and large Iranian companies have a higher priority than other dimensions. In addition, in large companies, intellectual and analytical competencies, expertise in risk management, governance, information
\end{abstract}




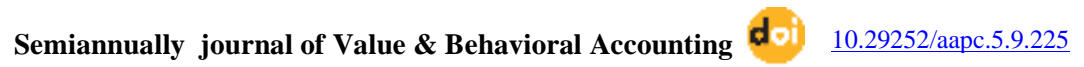

technology and quality frameworks have a higher priority than small and medium companies, which can be due to complex operating cycles and processes.

Key Word: Mixed Methods (Quantitative and Qualitative Methods), Grounded Theory, Internal Auditors, and Competency Model.

\section{Copyrights cc) (1)}

This license only allowing others to download your works and share them with others as long as they credit you, but they can't change them in any way or use them commercial. 


\section{مقاله يُوهشى}

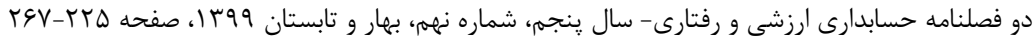

طراحى مدل و اولويتبندى ابعاد شايستَى مديران حسابرسى داخلى:

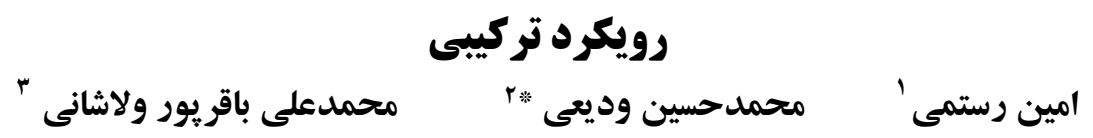

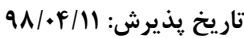

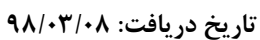

حسابرسى داخلى نوعى فعاليت اطمينان بخشى و مشاورهاى مستقل و بىطرفانه است كه با

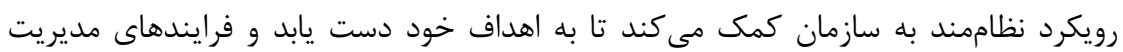
ريسك، كنترلهاى داخلى و راهبرى شركتى را بهبود بخشد. با توجه به اهميت روز افزون حسابرسى داخلى در سازمانها و تغيير نقش حسابرسى داخلى، مهارتها و شايستخى هاى جديد

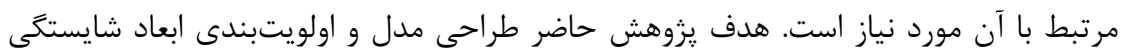
مديران حسابرسى داخلى با توجه به ويزگى هاى محيطى و شرايط حاكم بر حرفه حسابرسى تُ داخلى در ايران مىباشد. در اين راستا از روش تحقيق تركيبى استفاده شده است. به عبارت دئ ديخر،

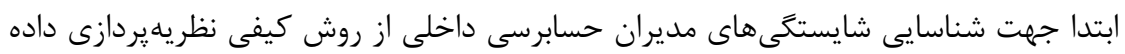
بنياد استفاده شده است. به اين منظور از طريق مصاحبههاى ساختار نيافته با 1 ا نفر از اساتيد

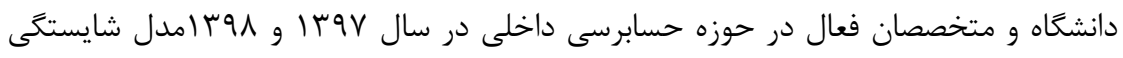
مديران حسابرسى داخلى ارائه گرديد. بر اساس اين مدل، مديران حسابرسى داخلى به منظور دستيابى به سطح مطلوب اثربخشى، بايد داراى مجموعهاى از شايستگى هاى فردى، فنى، مديريتى لهى و محيطى باشند. سيس در قسمت كمى تحقيق از طريق تحليل يرسشنامههاى دريافت شده از

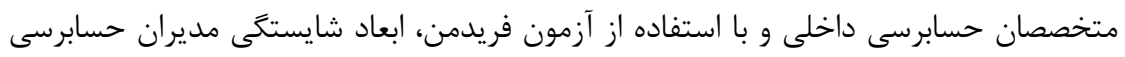
داخلى در شركتهاى كوجى، متوسط و بزرگ ايرانى اولويتبندى گرديد. نتايج يزوهش نشان مى دهد كه سه مولفه تجربه و سوابق كارى، تحصيلات دانشخاهى و تسلط بر مباحث حسابرسى

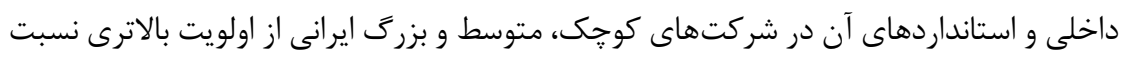
به ساير ابعاد شايستگى مديران حسابرسى داخلى برخوردارند. به علاوه در شركتهاى بزرى،

aminrostami@stu.um.ac.ir. دانشجوى دكترى حسابدارى دانشخاه فردوسى مشهد، مشهد، ايران

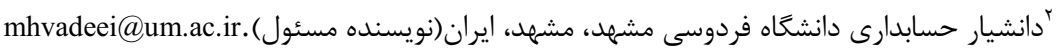

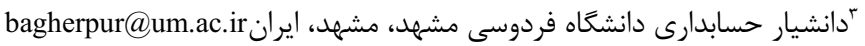


شايستخى هاى فكرى و تحليلى، تسلط بر مباحث مديريت ريسك، نظام راهبرى، فناورى اطلاعات

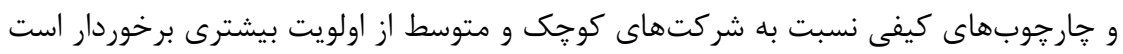

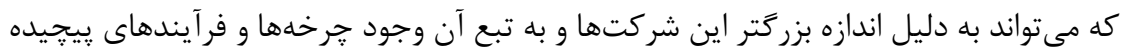
عملياتى باشد. وازگًان كليدى: روش تركيبى، تئورى دادهبنياد، حسابرسان داخلى، مدل شايستگى. 
طى ساليان اخير، در عرصه جهانى تحولات زيادى در محيط كسب و كار یديد آمده كه

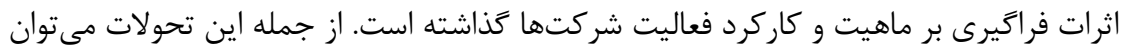

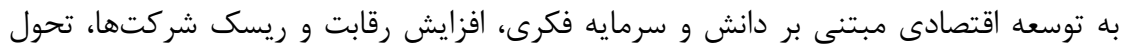

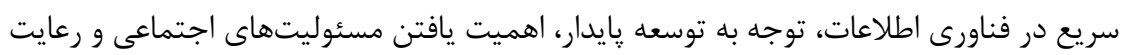

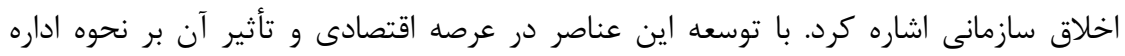

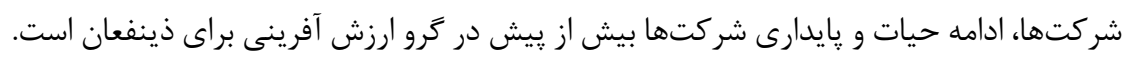

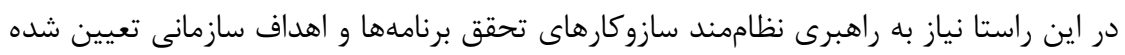

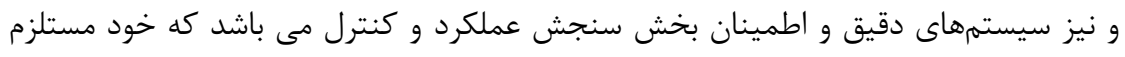

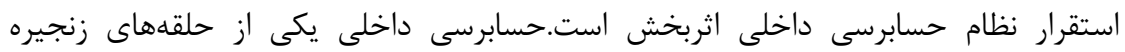

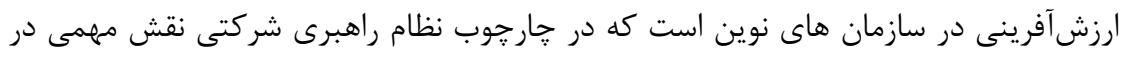

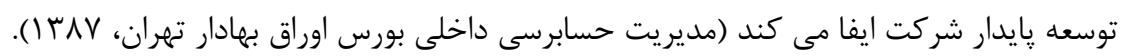

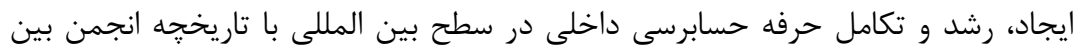

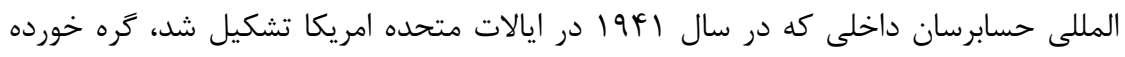

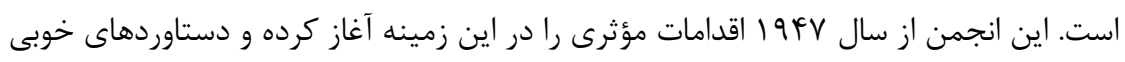

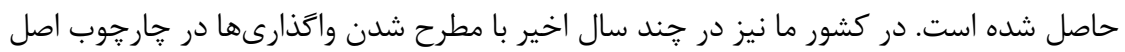

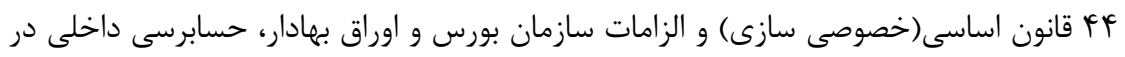

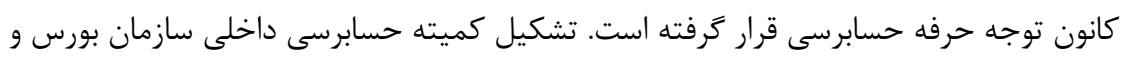

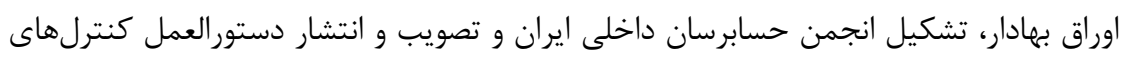

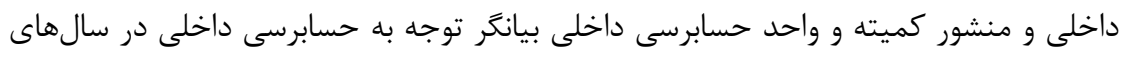

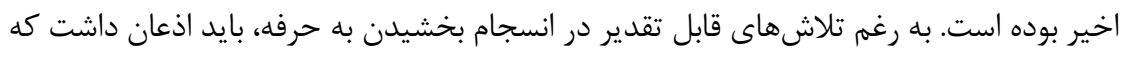

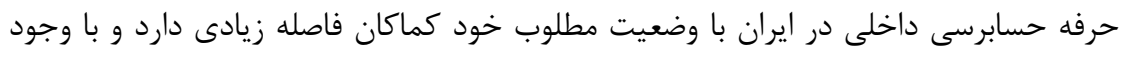

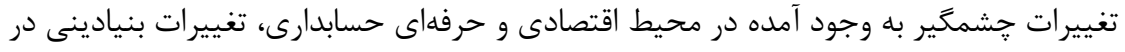

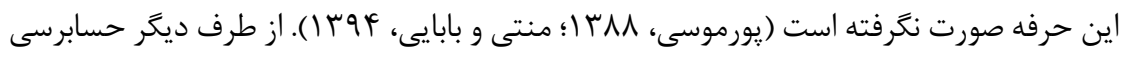

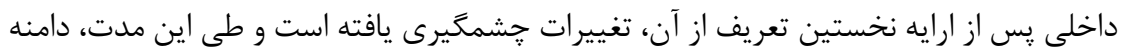

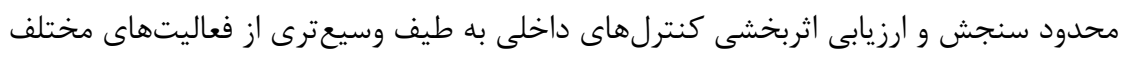

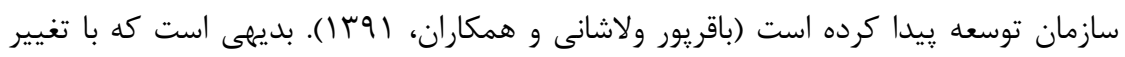

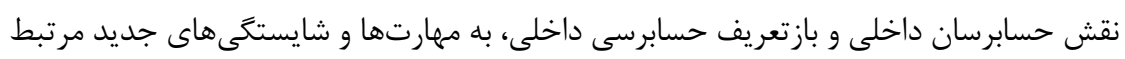
با آن نياز است. 
صلاحيت و شايستكى حسابرسان داخلى از جمله موضوعات با اهميت در راستاى دستيابى به

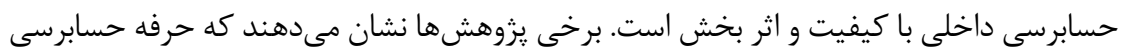

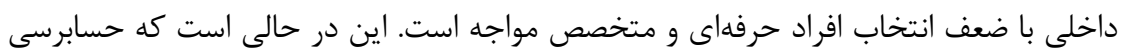

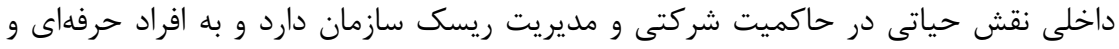

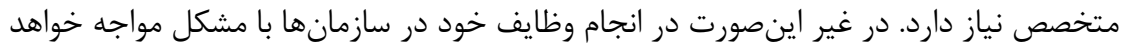

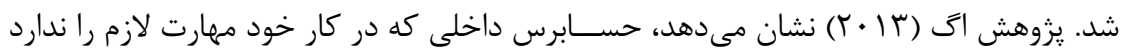
بر حاكميت شركتى آن سازمان اثر نامطلوبى كذاشته و امكان تقلب در سازمان ايجاد شده است إنا

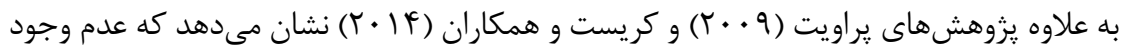

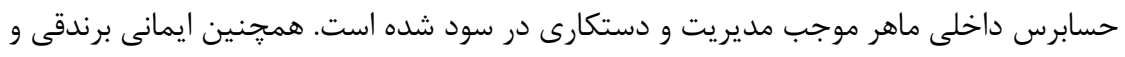

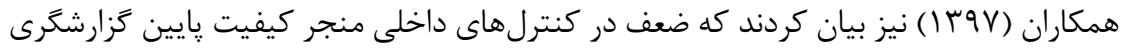
مالى و سرمايه كذارى ناكارا شده است.

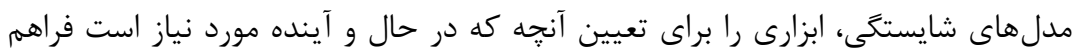

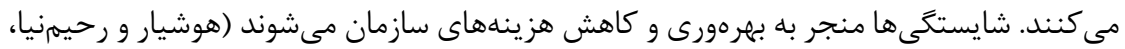

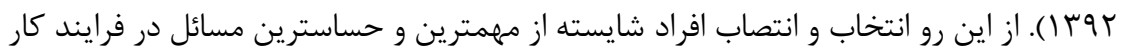

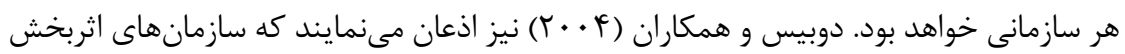

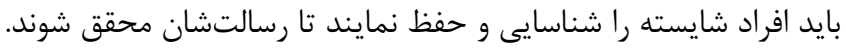

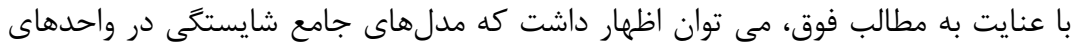

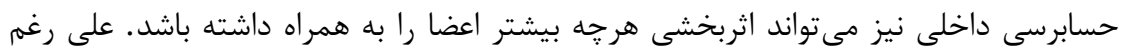
اهميت روز افزون نقش حسابرسى داخلى در سازمانها و تغيير نقش حسابرسى داخلى بله دانه

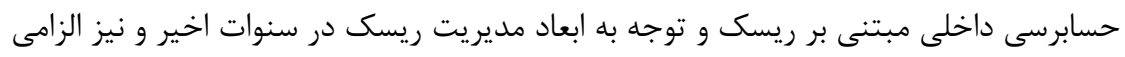

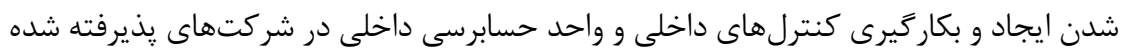

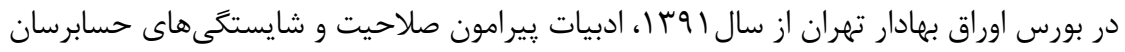

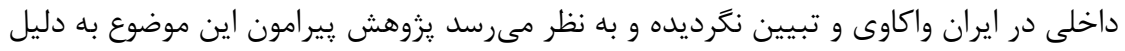

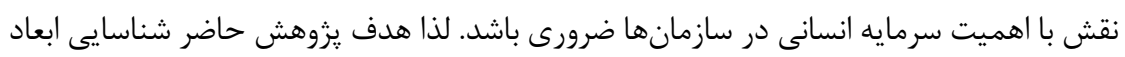
شايستگى مديران واحدهاى حسابرسى داخلى در شركتهاى ايرانى با استفاده از نظريه دادئ دادها

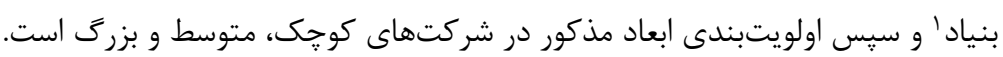

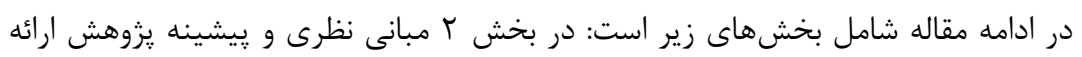

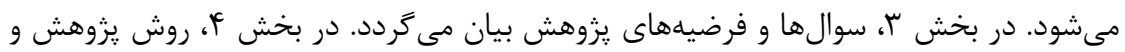

${ }^{1}$ Grounded theory 
نحوه تدوين مدل و اولويتبندى ابعاد شايستكى توضيح داده مىشود. در بخش ها يافتههاى

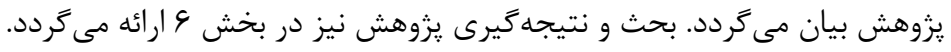

\section{r-مبانى نظرى و مرورى بر يِيشينه هيزوهش

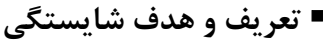

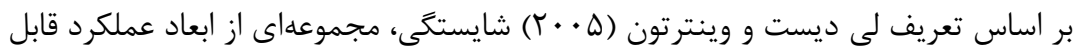
مشاهده مىباشد كه شامل دانش، مهارتها، كرايشات و رفتارها و نيز قابليتهاى دانى سازمانى و فرايند

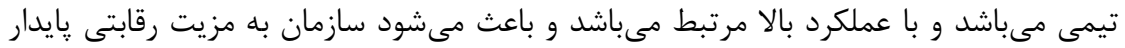

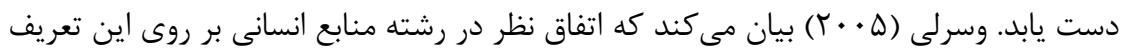

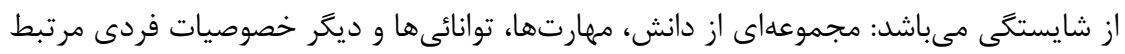

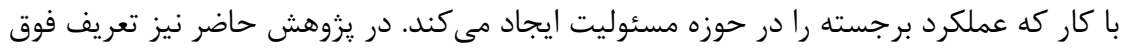

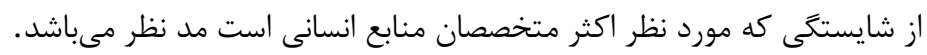

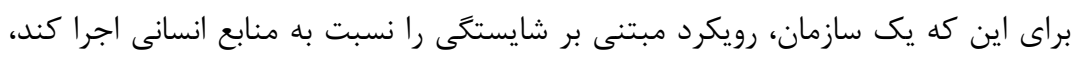
بايد شايستخى ها تعيين و مدلى توسعه ييدا كند كه اين شايستخى ها را توصيف كند (كوكران،

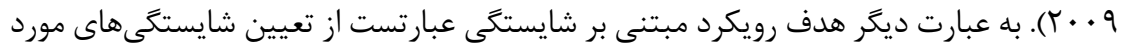

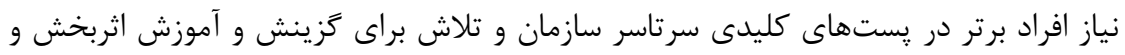

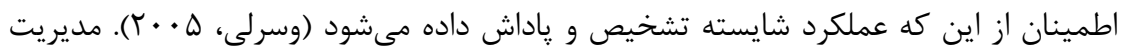
مبتنى بر شايستخى فرايندى تلفيقى است كه باعث قرار ترفتن افراد در جايخاه سازمانى مناسب،

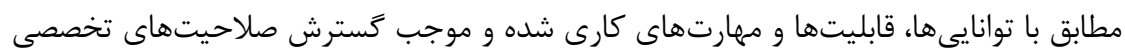

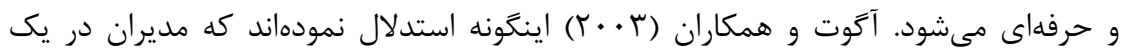
سازمان، درصورتى اثربخش مىباشند كه هم به وظايف شغلى و همم به تغييرات محيطى ياسخ

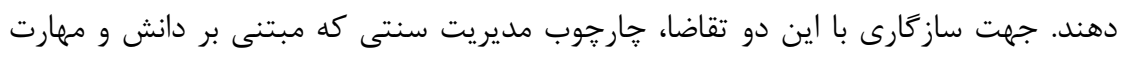

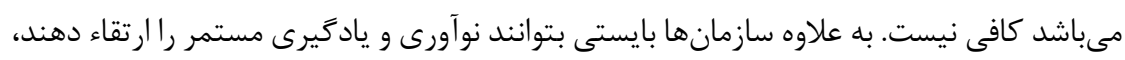

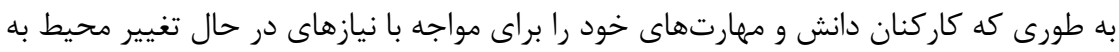

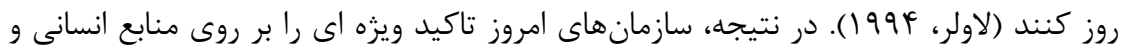
شايستخى هاى آنها دارند.

\section{• صلاحيت حسابرسان داخلى، بعد مهم كيفيت حسابرسى داخلى}

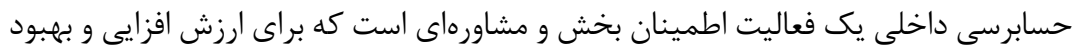

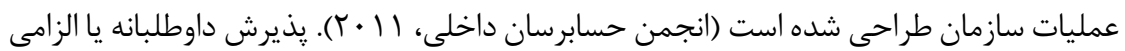

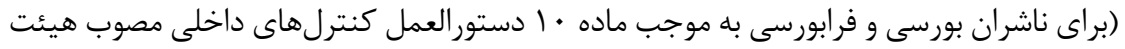


مديره سازمان بورس در سال (9 (1)) حسابرسى داخلى توسط شركتهاى ايرانى مستلزم صرف داري

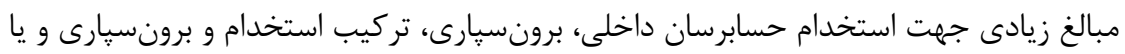

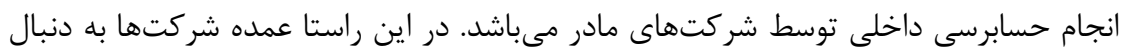

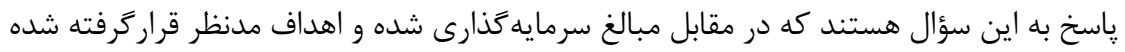

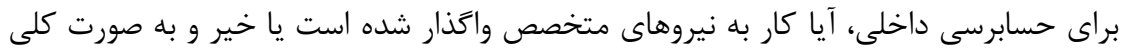

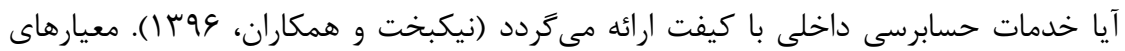

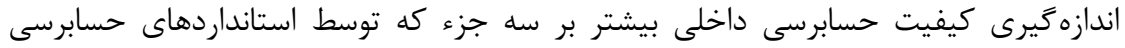

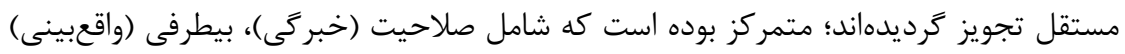

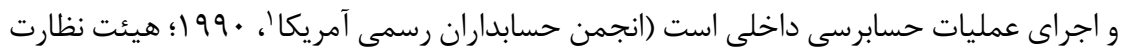

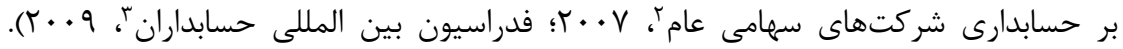

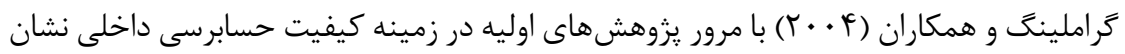

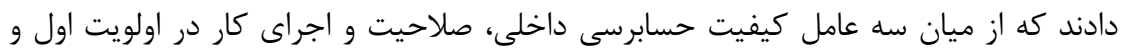

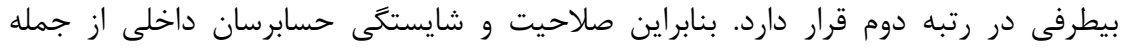

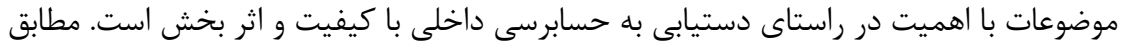

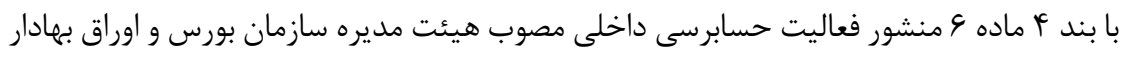

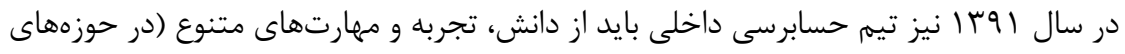

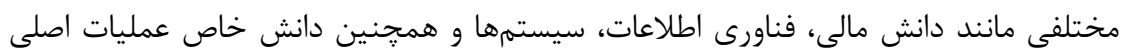

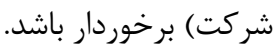

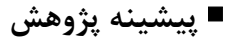

باوجود اهميت داشتن كيفيت حسابرسى داخلى و به طور خاص شائ دايستكى هاى حسابرسان

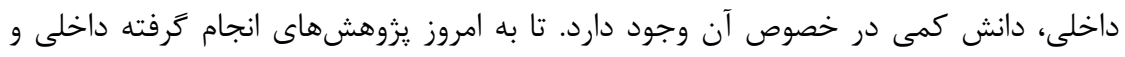

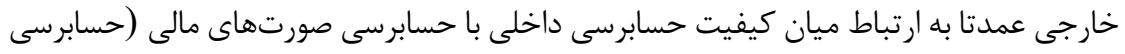

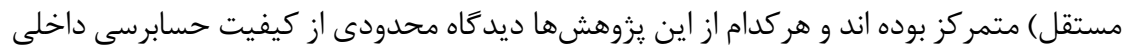

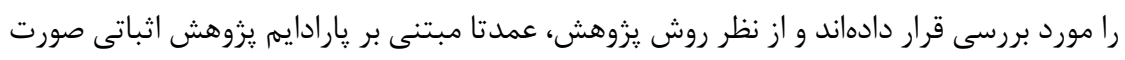

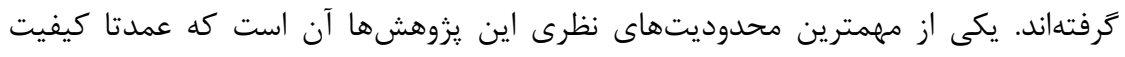

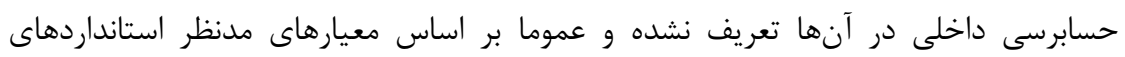

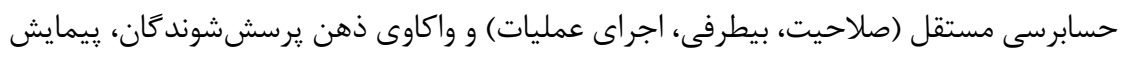


شدهاند. بر اساس استانداردهاى حسابرسى مستقل، حسابرس مستقل مىبايست قضاوت حرفهاى

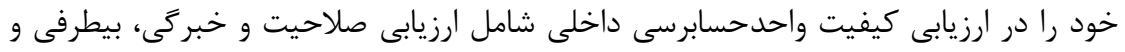

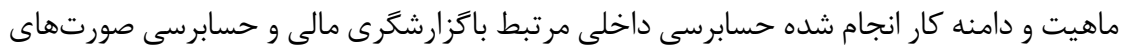

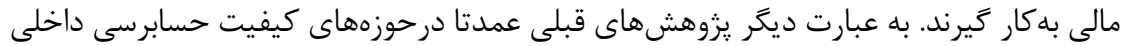
و ارتقاى عملكرد يا اثربخشى سازمان يا كيفيت كزارشكَرى مالى و نيز كيفيت حسابرسى دارئ داخلى و ميزان اتكاى حسابرسان مستقل صورت يذيرفته است و به صلاحيت و شايستكى حسابرسان

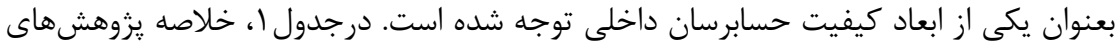

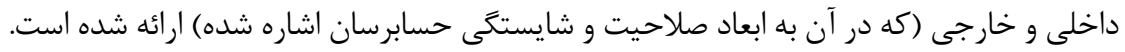

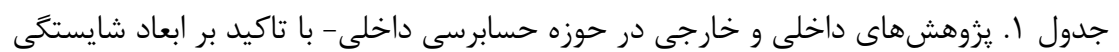

\begin{tabular}{|c|c|c|}
\hline \multicolumn{3}{|c|}{ حسابرسان داخلى } \\
\hline شايستًى حسابرسان به عنوان معيار & موضوع يزوهش & ئزوهشكران/ سال انجام \\
\hline تحصيلات، تجربه، آموزش، كَاهينامه & 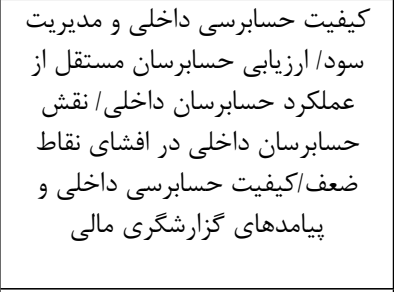 & 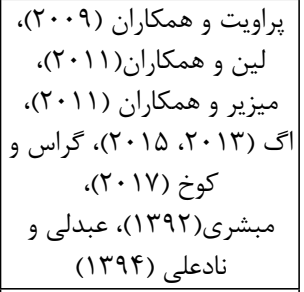 \\
\hline 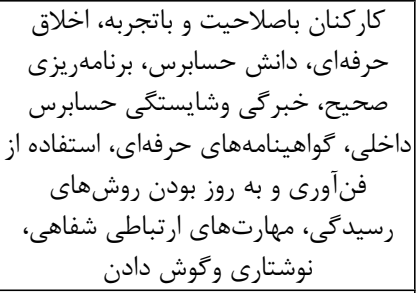 & بررسى اثربخشى حسابرسى داخلى & 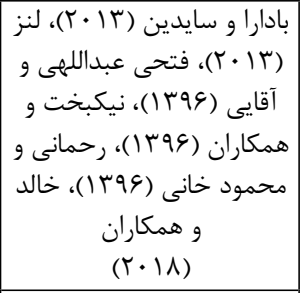 \\
\hline استفاده حسابرسى داخلى از فن آورىهاى & 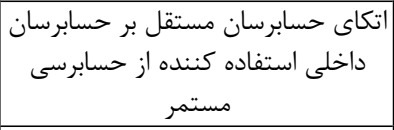 & ملسكيو و ساتن (Q • (Y) \\
\hline صلاحيت و خبركى، مهارتهاى فنى، & 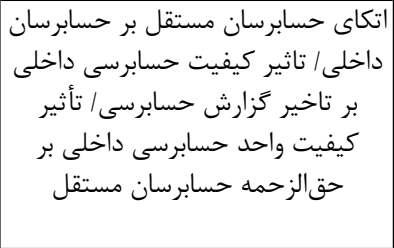 & 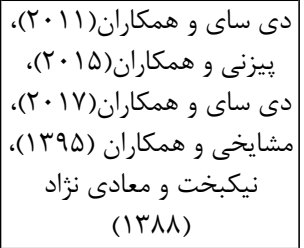 \\
\hline همكارى تيمى، مهارتهاى كامييوترى، & تاثير شايستگى ها بر عملكرد حسابرسى & وو و همكاران(Y) ( \\
\hline
\end{tabular}


بر اساس يزوهشهاى فوق الذكر، صلاحيت و شايستخى حسابرسان داخلى از جمله موضوعات

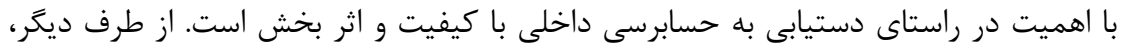

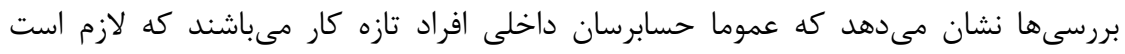

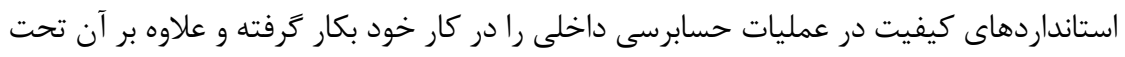

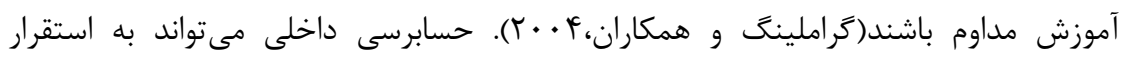

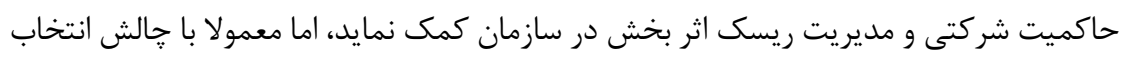

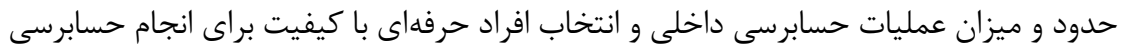

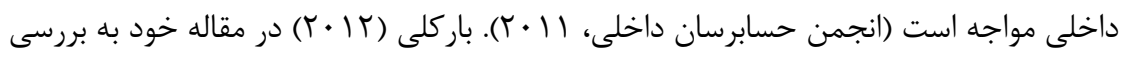

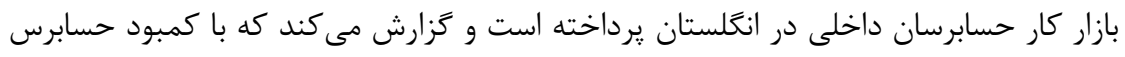

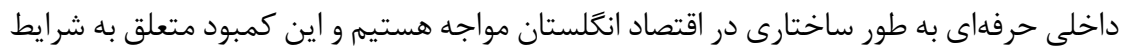

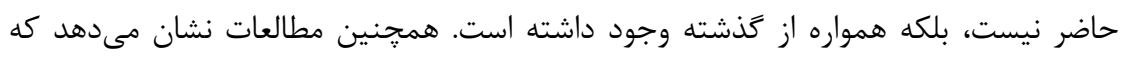

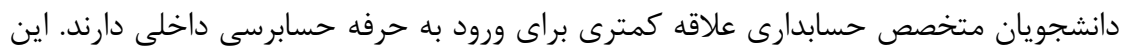

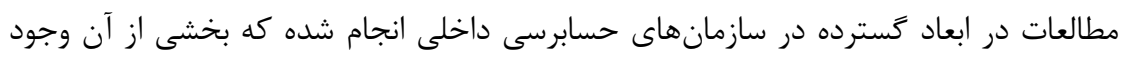

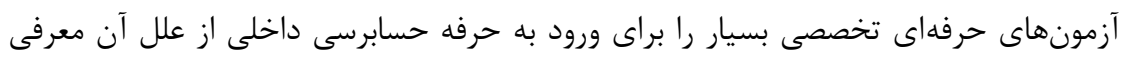

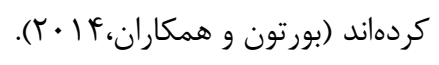

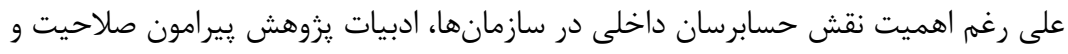

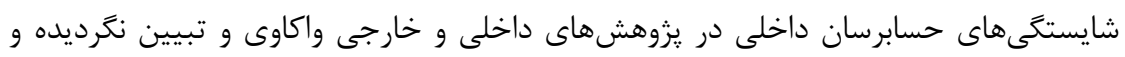

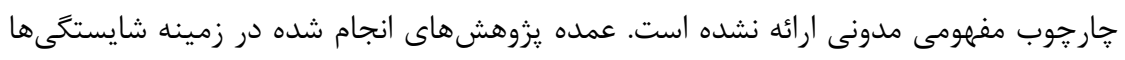

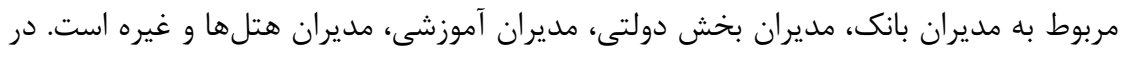

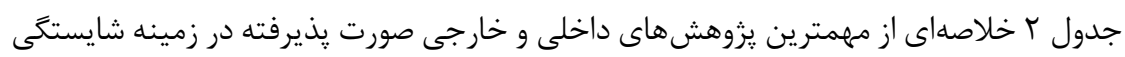

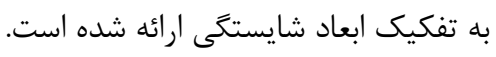

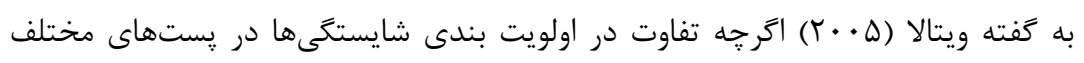

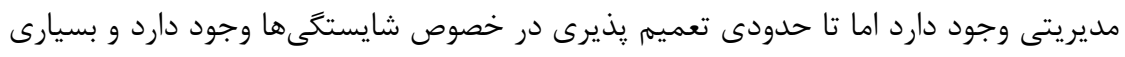

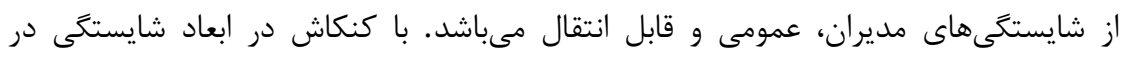

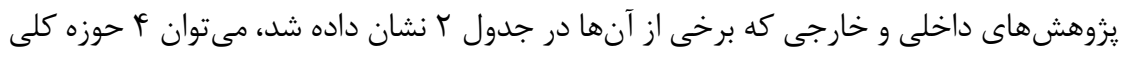

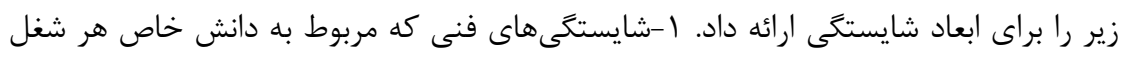

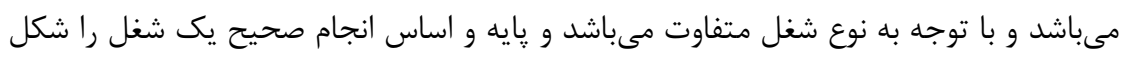

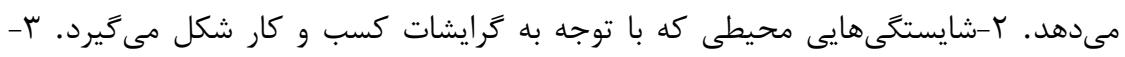

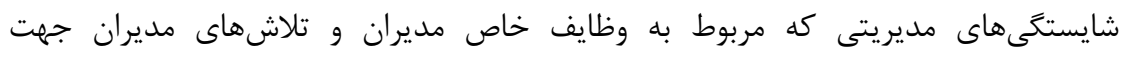




$$
\begin{aligned}
& \text { توانمندسازى زيردستان مىباشد. ₹-شايستكى هاى فردى كه مربوط به خصوصيات و ويزگكى هاى }
\end{aligned}
$$

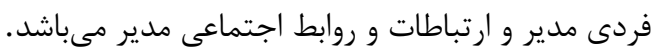

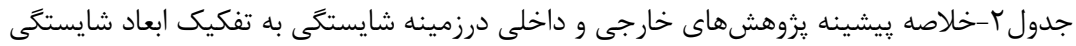

\begin{tabular}{|c|c|c|}
\hline ابعاد مدل شايستكى & | بزوهشكر & سال \\
\hline 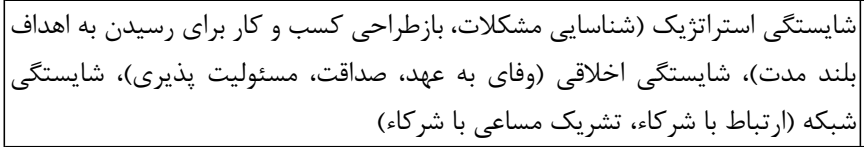 & 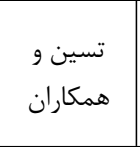 & $r .19$ \\
\hline |مهروره رهبرى، مهارت تجزيه و تحليل، مهارت فردى، مهارت ارتباطى، مهارت مديريت & 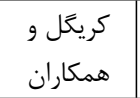 & $r .19$ \\
\hline |رهبرى يروزَ، آموزش، فرهنًَ بهبود مستمر، شش سيكَما، ارتباط با ذينفعان & مير & $r \cdot 19$ \\
\hline 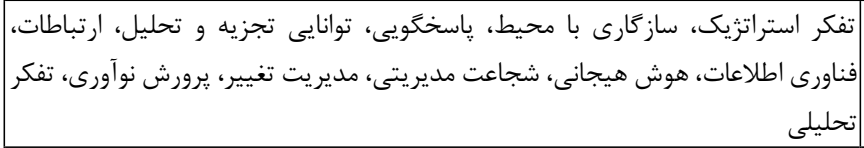 & 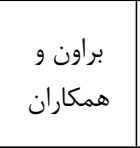 & $r .1 \Lambda$ \\
\hline استراتزى ارتباط قوى، همدلى، اجتناب از استرس، مذاكره موثر، اعتماد به نفس & 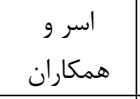 & $r .11$ \\
\hline 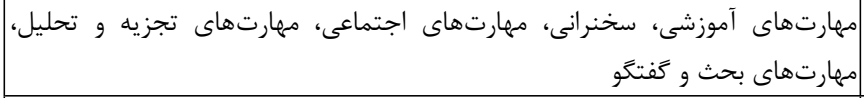 & 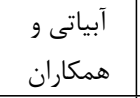 & $r \cdot I V$ \\
\hline 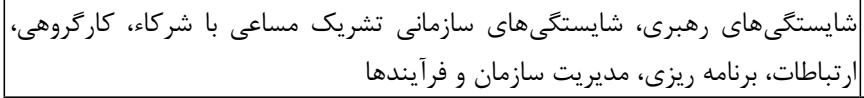 & | ترير و ون & r.le \\
\hline 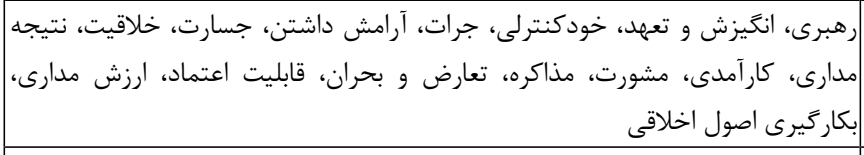 & | دريموسيس و & $r \cdot 1 r$ \\
\hline 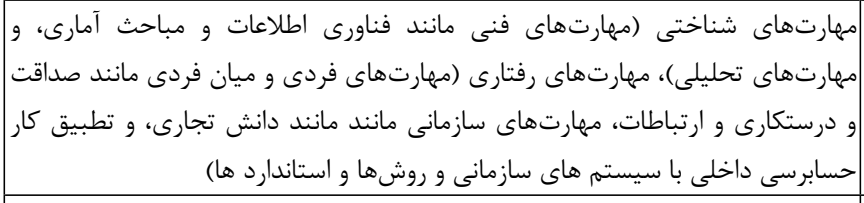 & همكاران & $r .11$ \\
\hline 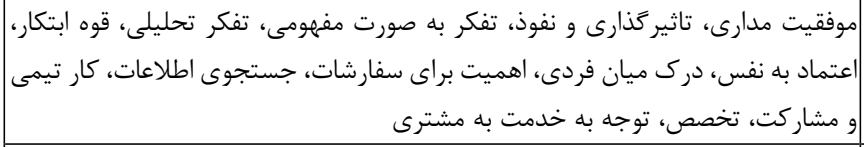 & لى & $r \cdot l \cdot$ \\
\hline 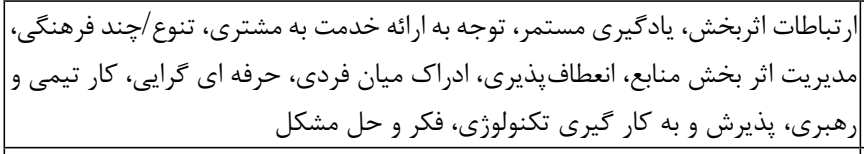 & كوكران & $r \cdot . q$ \\
\hline 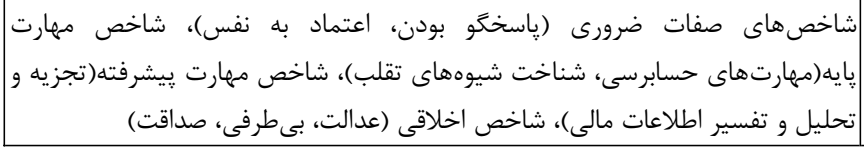 & همكاران & 1499 \\
\hline
\end{tabular}


دو فصلنامه حسابدارى ارزشى و رفتارى، سال ينجم، شماره نهم، بهار و تابستان 99"1

\begin{tabular}{|c|c|c|}
\hline ابعاد مدل شايستخىى & يزوهشگر & 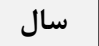 \\
\hline تحمل ابهام، مديريت برقرارى ارتباط، تسهيم دانش، مديريت ريندهنگًارى و نوآورى فناورى، تفكر انتقادى، & تركمانى و مهديلو & $1 r 90$ \\
\hline ويثَّى هاى شخصيتى، نحرشى، رفتارى & فر هادى نراد & 1rar \\
\hline كردن صحيح شعبه عمومى، دانش تخصصيى، بازاريابى، مديريت منابع انسانى، آحاهى از محيط، اداره & 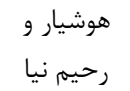 & 1495 \\
\hline
\end{tabular}

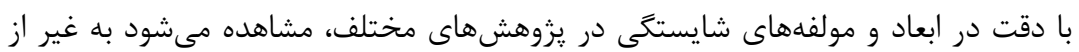

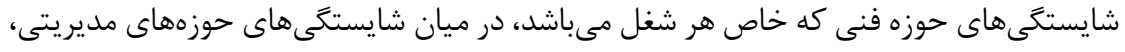

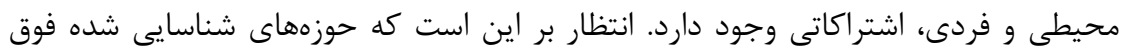

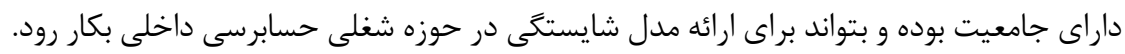

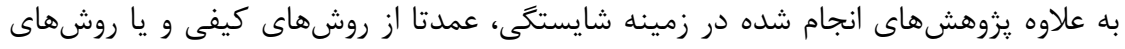

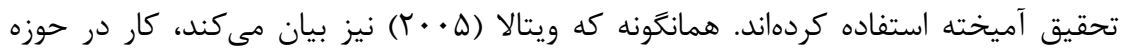

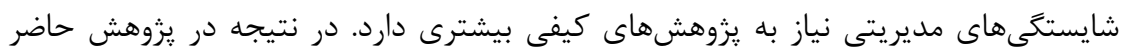

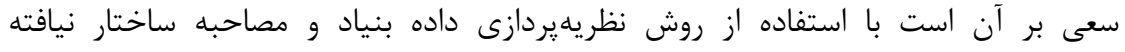

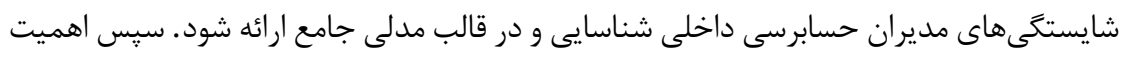

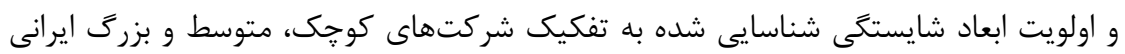
بررسى و ارائه گردد.

$$
\begin{aligned}
& \text { r-سوالها و فرضيه هاى يثوهش }
\end{aligned}
$$

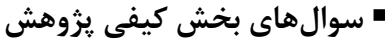

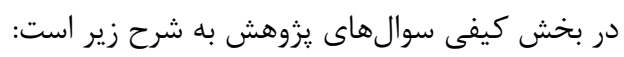

$$
\begin{aligned}
& \text {-شايستكى هاى مديران واحد حسابرسى داخلى شامل خه اجزاء و ابعادى است؟ }
\end{aligned}
$$

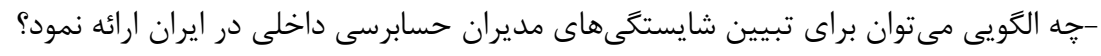

$$
\begin{aligned}
& \text { در بخش كمى سوال يزوهش به شرح زير است: }
\end{aligned}
$$

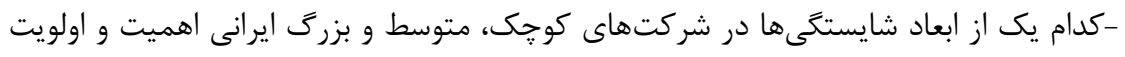

$$
\begin{aligned}
& \text { بيشترى دارد؟ } \\
& \text { فرضيه اصلى بخش كمى يزوهش به شرح زئ زير است: }
\end{aligned}
$$

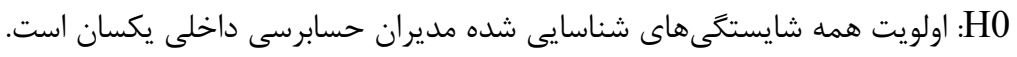


H1 حداقل يك شايستگى داراى اولويت متفاوتى از ساير شايستخىهاى شناسايى شده مديران

$$
\text { حسابرسى داخلى است. }
$$

فرضيههاى بخش كمى يزوهش به تفكيك شركتهاى بزرگ، متوسط و كوجٍى ايرانى به شرح

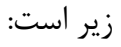

فرضه فرعى اول: حداقل يك شايستگى داراى اولويت متفاوتى از ساير شايستگى هاى شناسايى

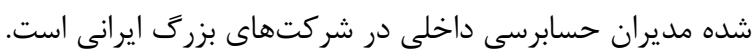

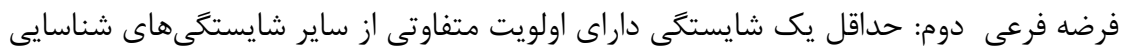

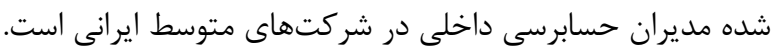

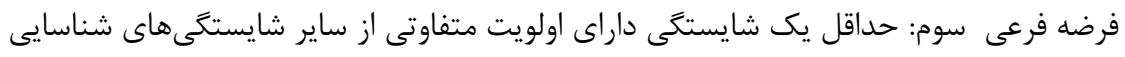

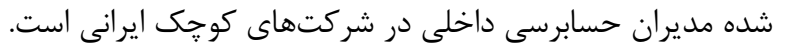

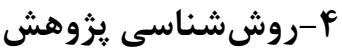

در اين يزوهش، از روش تحقيق تركيبى اكتشافى استفاده شده است. به عبارت ديكر، ابتدا جهت تدوين مدل شايستخى مديران حسابرسى داخلى از روش كيفى نظريهايردازى دادئ داده بنياد و

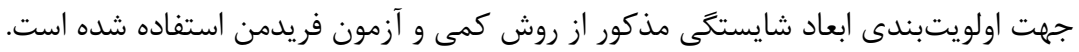

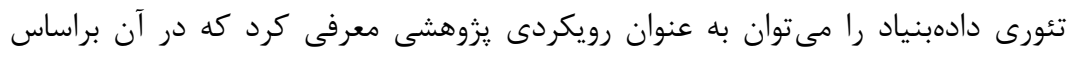

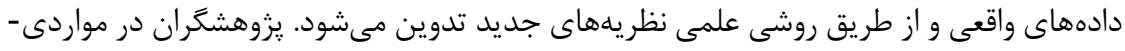

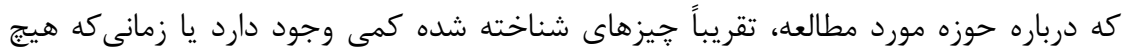

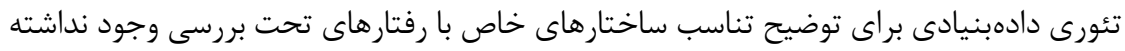

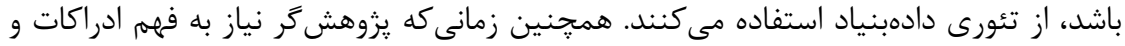

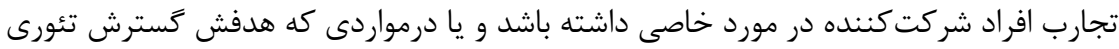

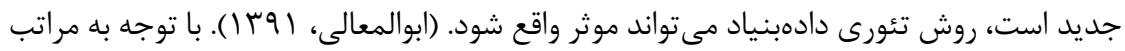
فوق و در راستاى ياسخكويى به سوالهاى بخش كيفى يزوهش كه شناسايى ابعاد شايستكى

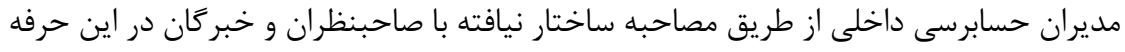

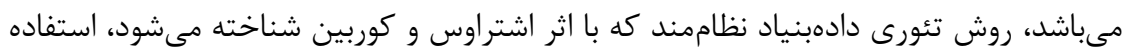

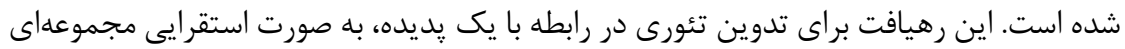

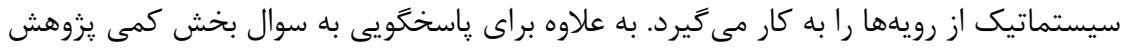

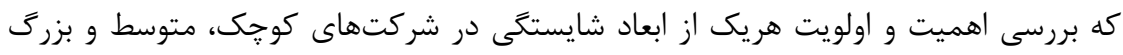
ايرانى از طريق جمع آورى نظرات متخصصان و خبر كان با استفاده از يرسشنامه مى بـاشد، از آزمون

$$
\text { فريدمن استفاده شده است. }
$$




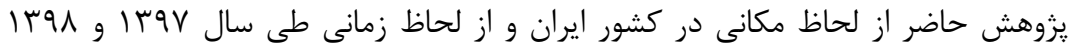

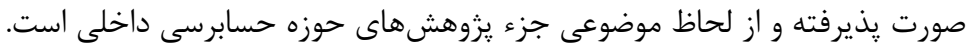

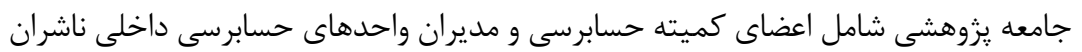

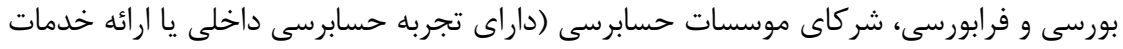

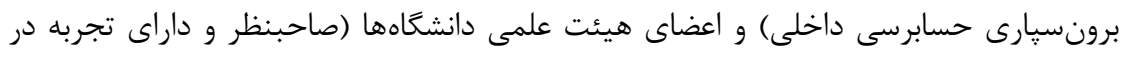

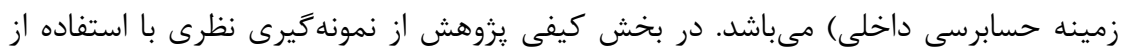

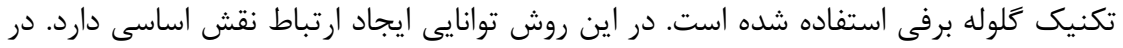

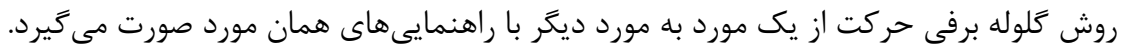

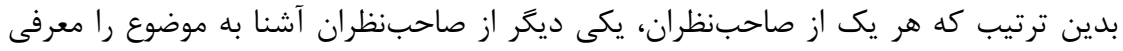

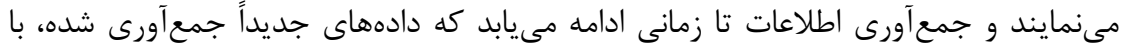

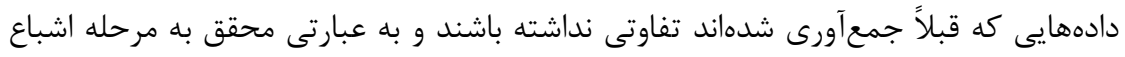

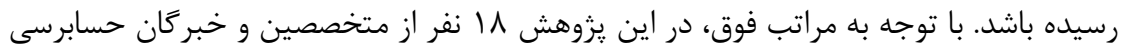

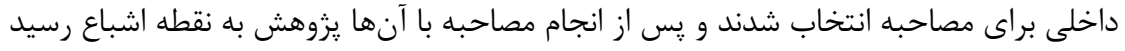

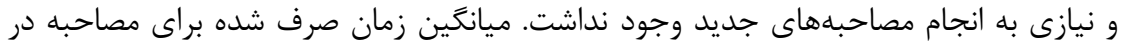

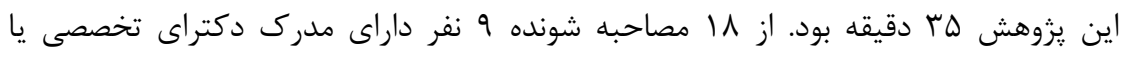

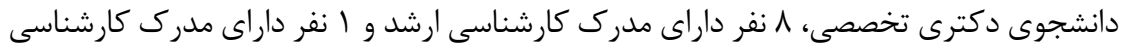

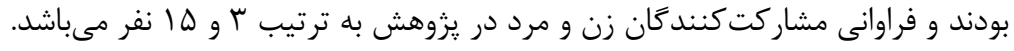

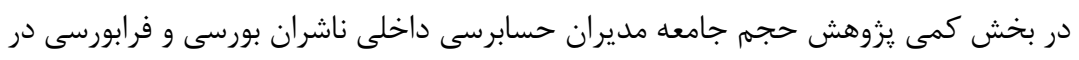

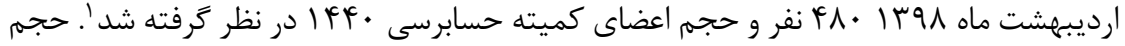

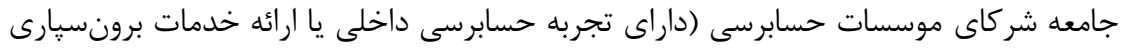

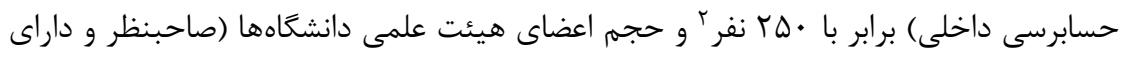

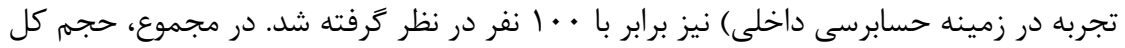

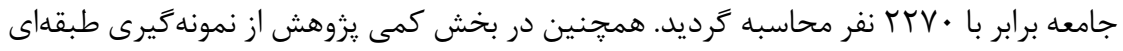

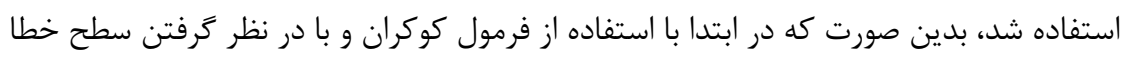

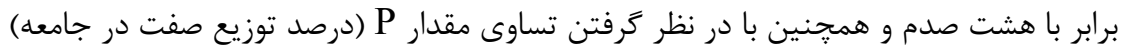

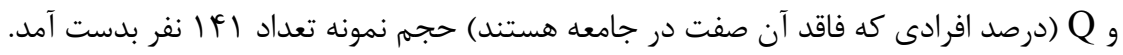

$$
\mathrm{n}=\frac{2270 \times 1.96^{2} \times 0.5 \times 0.5}{0.08^{2}(2270-1)+1.96^{2} \times 0.5 \times 0.5}=141
$$

${ }^{1}$ https://codal.ir \& http://tse.ir/ \& https://www.ifb.ir/

${ }^{2} \mathrm{http}: / /$ www.iacpa.ir/ 
سيس با استفاده از روش انتساب متناسب از جامعه، حجم نمونه 9 نفر براى اعضاى هيات علمى،

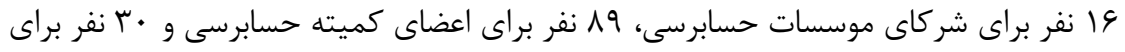

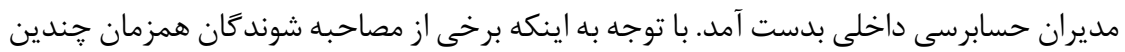

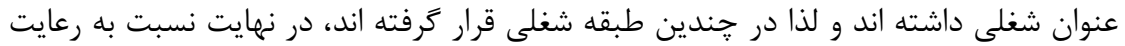
حداقل تعداد اعضاى نمونه در هر طبقه اطمينان حاصل شد. به اين صورت كه تعداد هر طبقه از

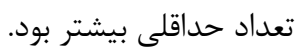

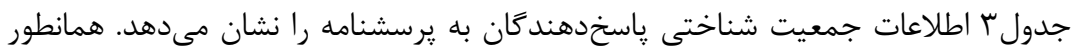
كه مشاهده مى

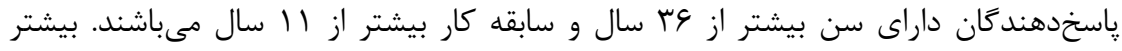

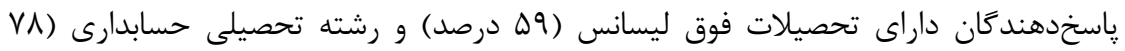

جدول r: اطلاعات جمعيت شناختى ياسخدهندًان يرسشنامه

\begin{tabular}{|c|c|c|c|}
\hline 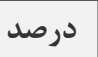 & $|F|=|F|=\mid$ & ويزگى ها & \\
\hline$\% \pi r$ & rl & ازن & \multirow[t]{2}{*}{ 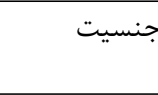 } \\
\hline$\% \mathrm{VA}$ & $11 \cdot$ & مرد & \\
\hline$\%$ & 9 & كمتر از ·r سال & \multirow[t]{4}{*}{ سن } \\
\hline$\%$ \% & rq & • • • تا هr سال & \\
\hline$\%$ & FF & 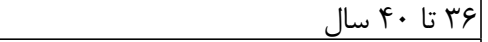 & \\
\hline$\% \mathrm{rV}$ & $\Delta r$ & | الج سال و بيشتر & \\
\hline r & Fq & مدير حسابرسى داخلى & \multirow[t]{4}{*}{ كنوان شغلى' } \\
\hline $94 \%$ & $9 \cdot$ & عضو كميته حسابرسى & \\
\hline$\% 19$ & $r V$ & شريك موسسه حسابرسى (حسابدار رسمى) & \\
\hline $18 \%$ & rT & عضو هيات علمى دانشكاه & \\
\hline$\% \pi r$ & rl & |ه تا • ا سال & \multirow[t]{3}{*}{ سابقه كار } \\
\hline$\%$ & FF & || 11 تا هال سال & \\
\hline$\% \mathrm{qV}$ & 99 & | 19 سال و بيشتر & \\
\hline$\% 19$ & $r$ & ليسانس & \multirow[t]{3}{*}{ تحصيلات } \\
\hline$\% .09$ & $\Lambda \mu$ & فوق ليسانس & \\
\hline$\%$ \% & ro & - مكترى & \\
\hline$\% \mathrm{~V}$ & $11 \cdot$ & 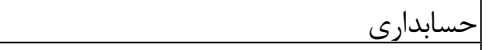 & \multirow{3}{*}{ شته تحصيلى } \\
\hline$\%$. & 14 & حسابرسى & \\
\hline$\% 1 \mathrm{r}$ & $\mid \mathrm{V}$ & |مديريت، اقتصاد يا ساير رشتهها & \\
\hline
\end{tabular}

' برخى از مصاحبه شوندكان همزمان جندين عنوان شغلى داشته اند و لذا در جدول در جندين طبقه شغلى قرار كرفته اند. 
(1)

\section{- بخش كيفى}

به منظور تحليل دادههاى حاصل از مصاحبه ساختار نيافته و عميق از روش نظاممند تئورى

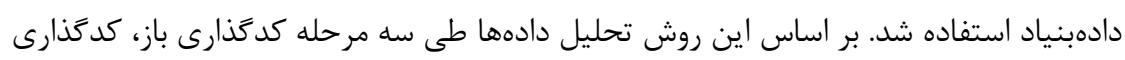

$$
\text { محورى و كدگذارى گزينشى(انتخابى) انجام مىشود. }
$$

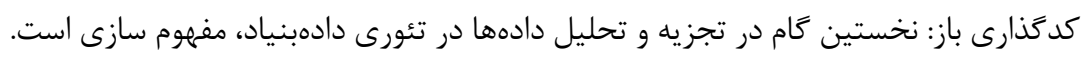

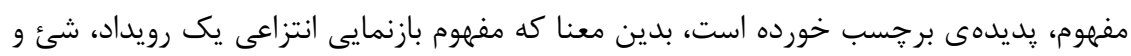

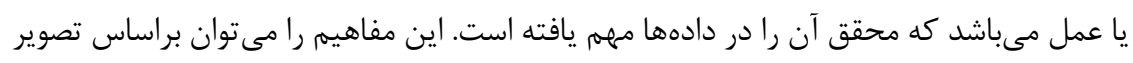

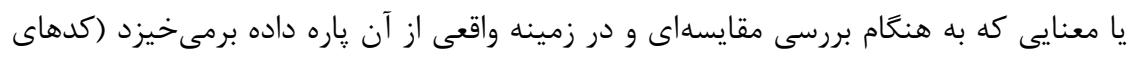

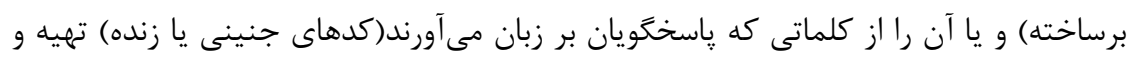

انتخاب نمود.

دراين يزوهش نيز يس از انجام هر مصاحبه، متن مربوط به آن سطر به سطر مورد بررسى

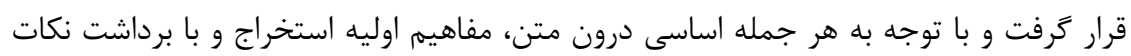
كليدى و انجام كدگذارى باز، مصاحبه بعدى انجام مى گرفت. اين رويه تا زمانى ادامه بيد بيدا نمود

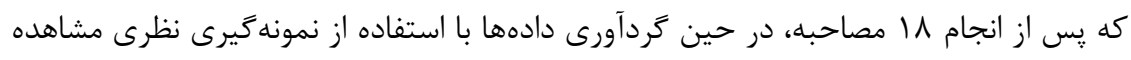

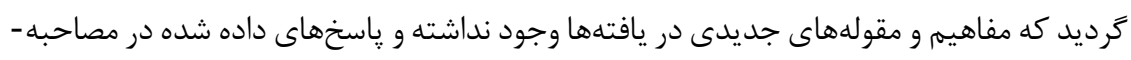

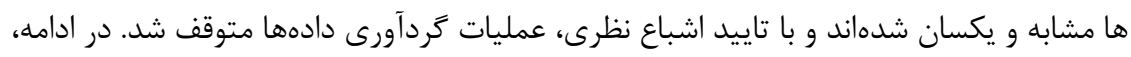

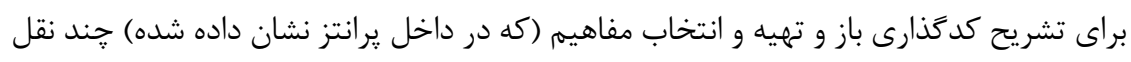

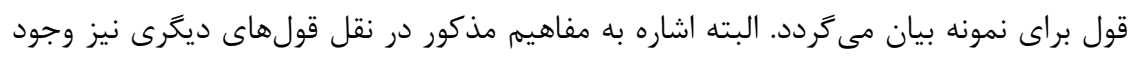

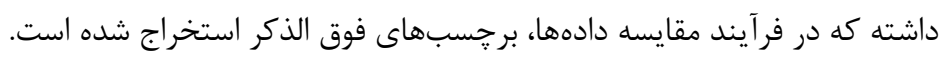

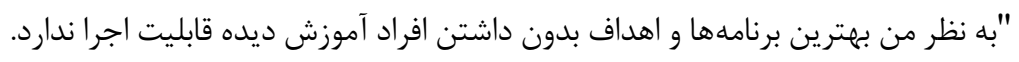

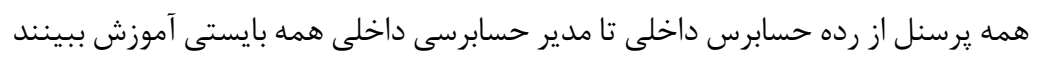

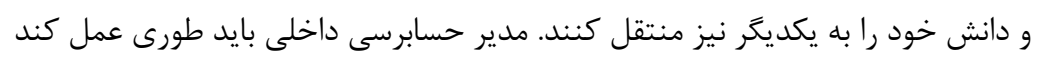

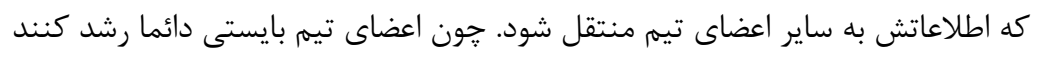

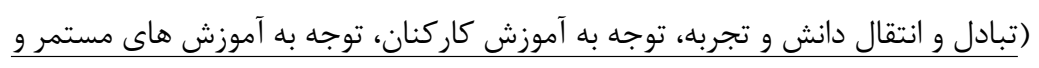

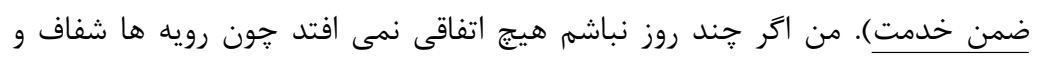
مشخص است و ساير اعضا بر حسب سلسله مراتب وظايف محوله را به نحو احسن انجام

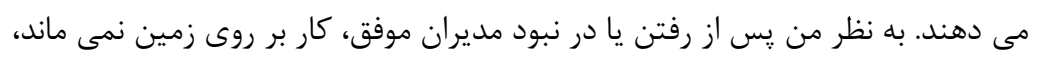

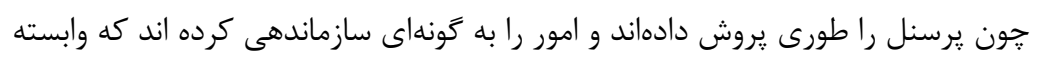
به خودشان نيست (توجه به توانمندى افراد، توانمندسازى كاركنان، جانشين يرورىى، مدير يرورى). اخر از نيروهاى داخلى براى تصدى يستهاى مديريتى استفاده شود، انخيزه 
كار كنان تقويت خواهد شد. مثلا من مديران حسابرسى داخلى شركتهاى فرعى هلدينَ

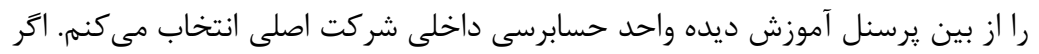

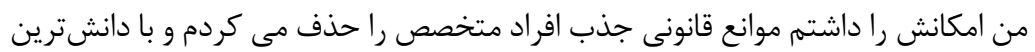

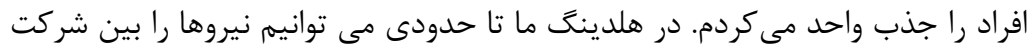

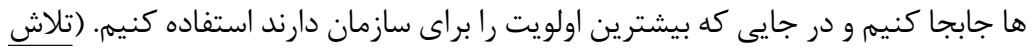

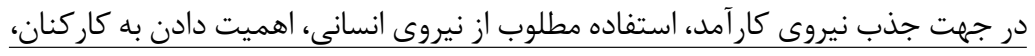
ايجاد انخيزه در كاركنان، حمايت از كاركنان در اجراى برنامه هارا)."

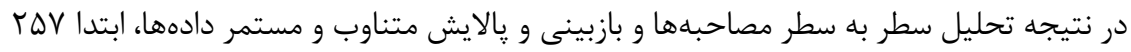

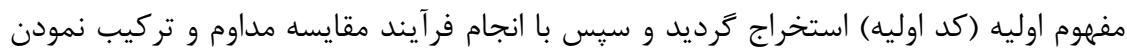

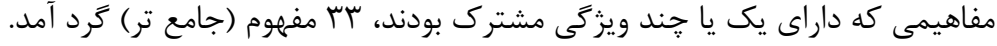

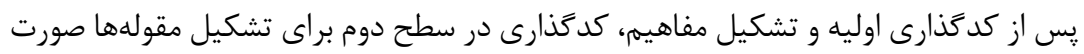

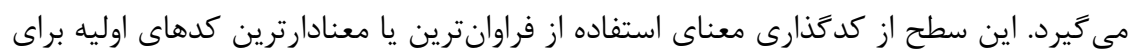

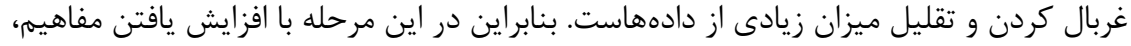

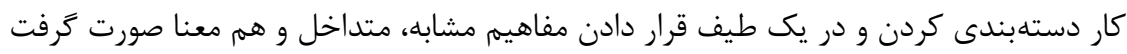

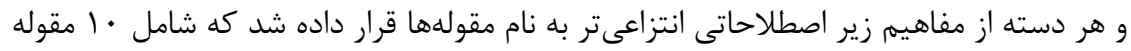

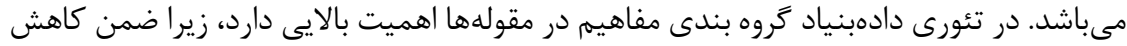

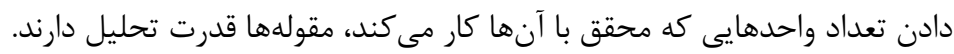

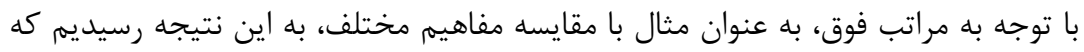

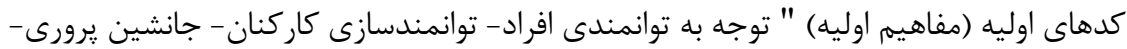
مديريرورى- تبادل و انتقال دانش و تجربه- توجه به آموزش كاركنان- توجه به به آموزش های

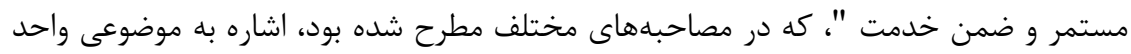

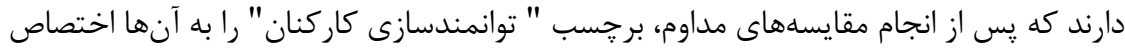

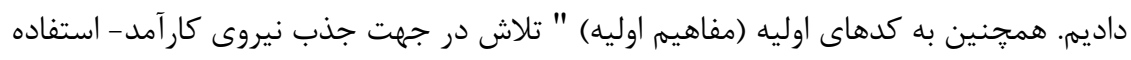

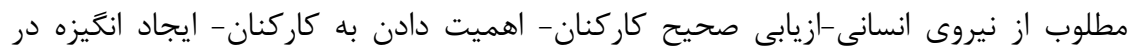

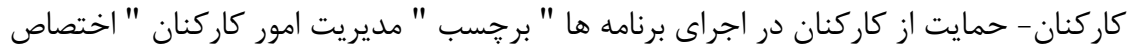

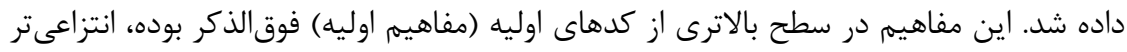

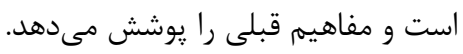

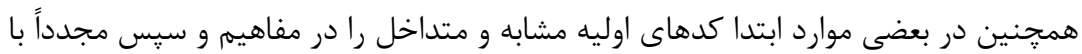

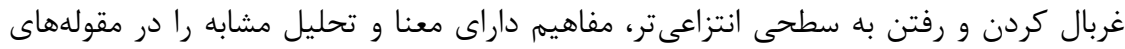

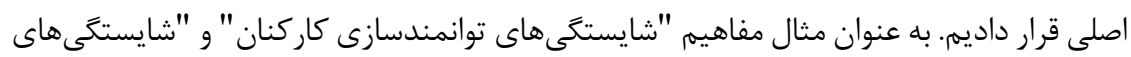


مديريت امور كار كنان " در سطحى انتزاعىتر زير مجموعه مقوله اصلى "شايستكىهاى مديريت

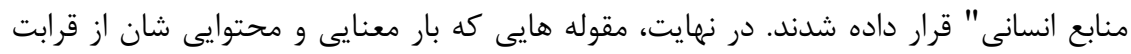

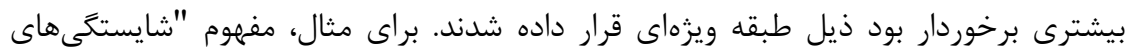

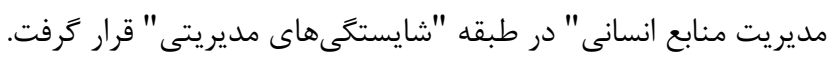

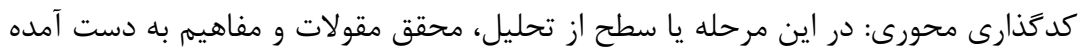

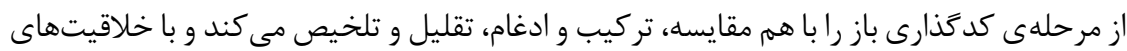

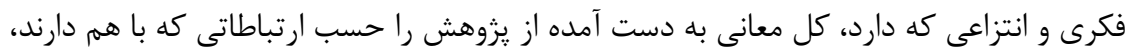

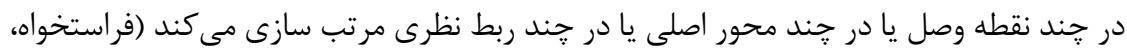

ضمن تاكيد مجدد بر اين نكته كه هيج مرز مشخصى ميان مرحله كدگذارى باز و كدگذارى

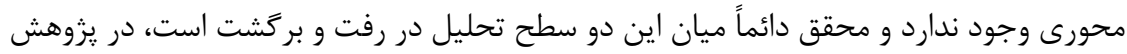

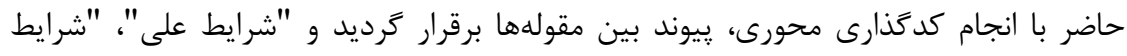
مداخله

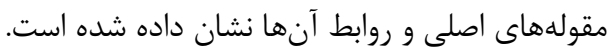

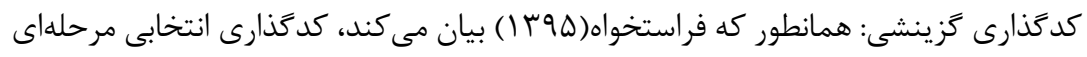

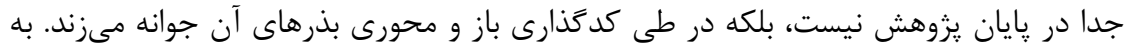

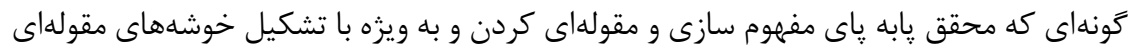

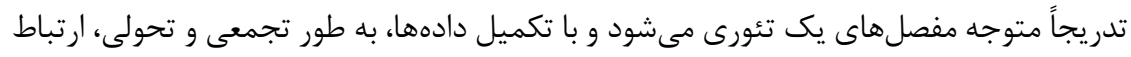

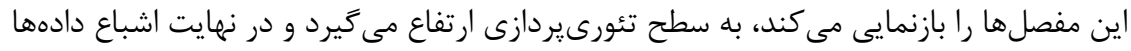

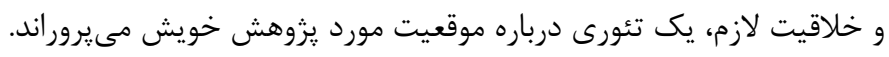

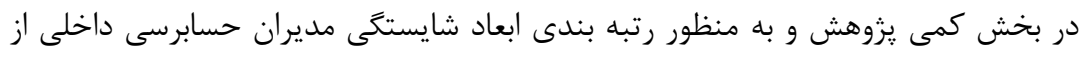

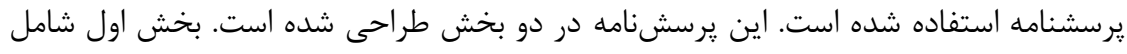

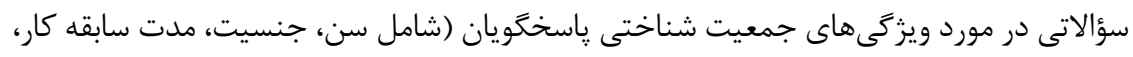

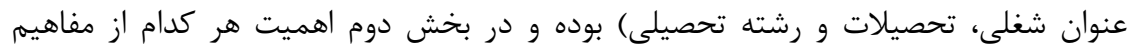

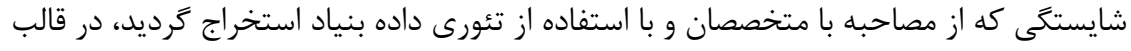

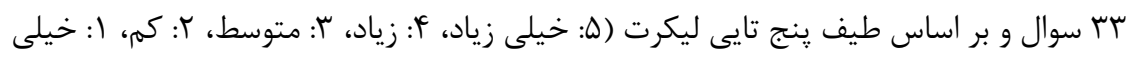
كم) مورد بررسى قرار كرفت.

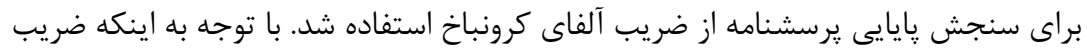

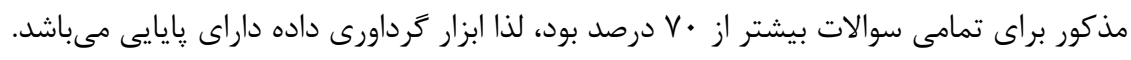


همجنين به منظور بررسى روايى يرسشنامه نيز پِ إن از طراحى يرسشنامه و مراجعه به له نفر خبره

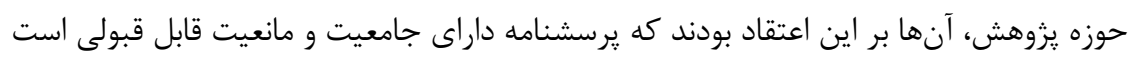
و به شكل مناسبى دسته بندى و ارائه شده است.

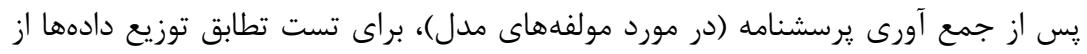

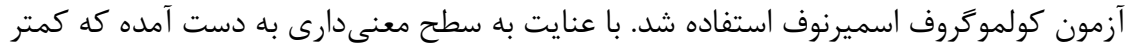

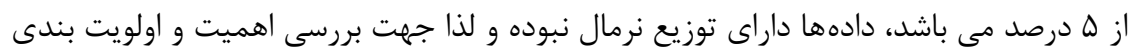

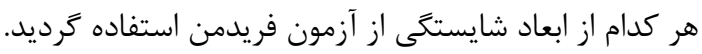

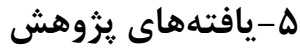

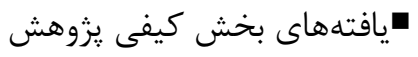

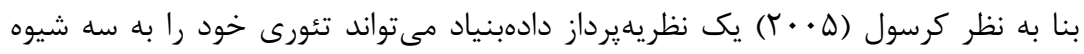

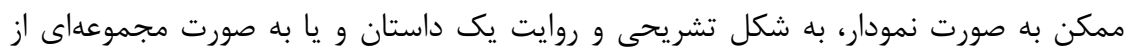

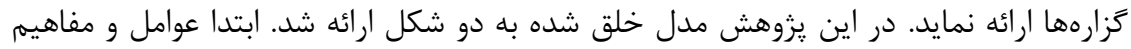

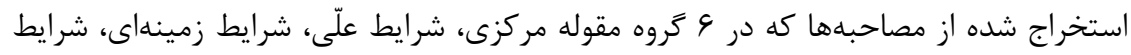

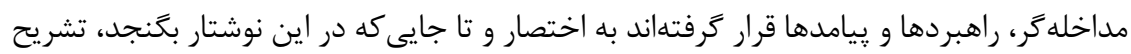
شده و سيس از طريق نمودار مدل شايستخى مديران حسابرسى داخلى ارائه كرديد.

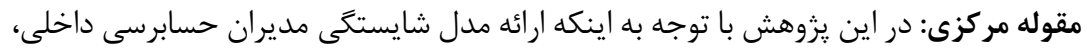

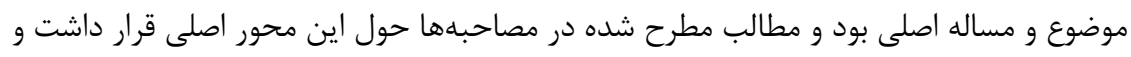

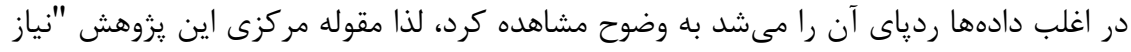

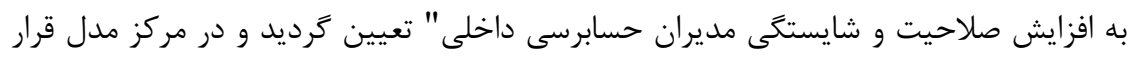

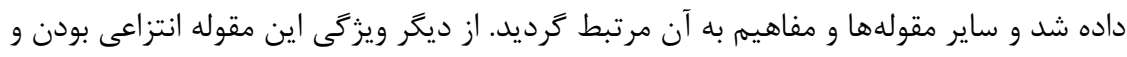
جامعيت آن است.

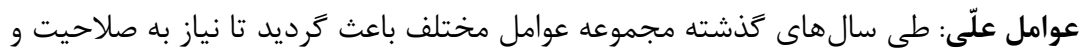

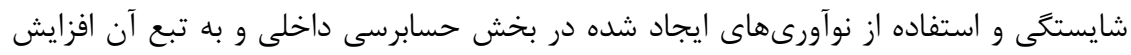

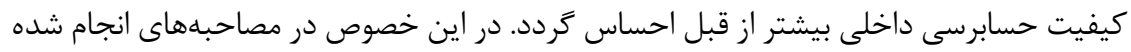

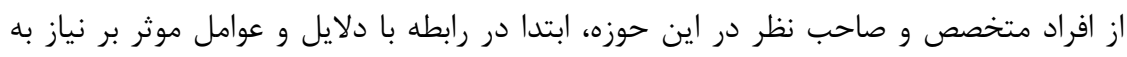

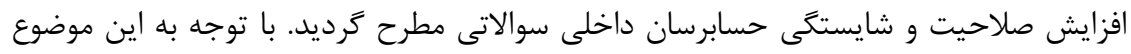

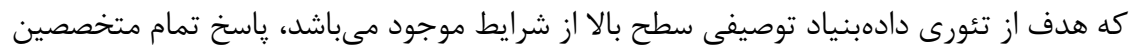

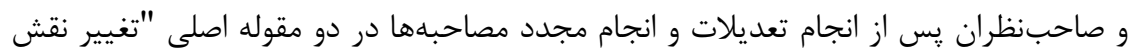




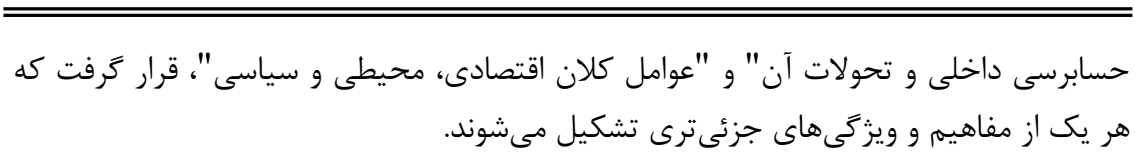

تغيير نقش حسابرسى داخلى و تحولات آن: حرفه حسابرسى داخلى يس از ارئ ارايه نخستين

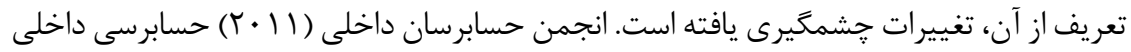
را نوعى فعاليت اطمينان بخشى و مشاورهاى مستقل و بعى طرفانه كه با هدف ارزش آفرينى و بهبود عملكرد سازمان انجام مىشود توصيف مى كند. حسابرسى داخلى با رويكرد نظاممند به سازمان كمك مى كند تا به اهداف خود دست يابد و فرايندهاى مديريت ريسك، كنترلهاى داخلى و و راهبرى شركتى را بهبود ببخشد. تعريف جديد انجمن حسابرسى داخلى از حسابرسى داخلى در

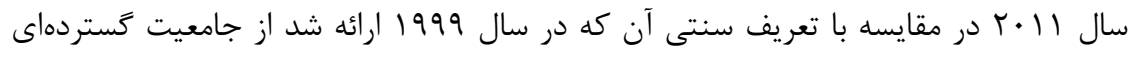
برخوردار است و بر اساس تعريف جديد خدمات اطمينان بخش و مشاوه را در بر مى گيرد. به

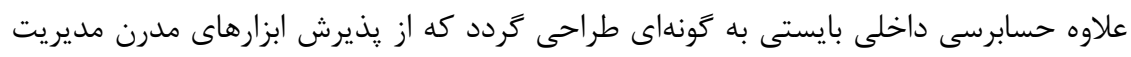
ريسك، كفايت و اثربخشى اين ابزارها و همجنين كمك به واحدهائ بإنى سازمانى براى كاهش ريسكها اطمينان حاصل شود. بديهى است كه با تغيير نقش حسابرسان داخلى و تحولات روز به

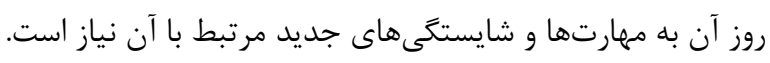
عوامل كلان اقتصادى، محيطى و سياسى: روند تغييرات اقتصادى، سياسى، اجتماعى و فرهنگى جوامع در سطح ملى و بينالمللى در عمل با وجود آثار يروانهاى بر ساير حوزههاى

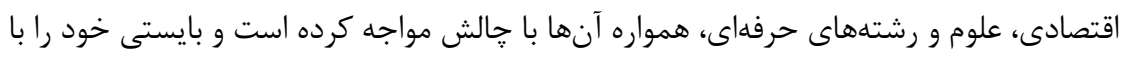

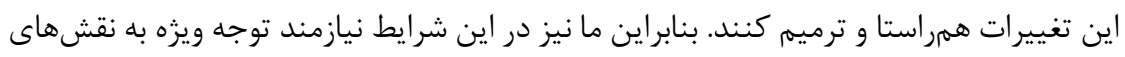
جديد حسابرسى داخلى در سازمانها هستيم و با توجه به اين موضوع كه گزارشهاى صادره توسط واحد حسابرسى داخلى مى تواند به عنوان جشم سوم مديريت نقش آفرينى كند، بازنگرى

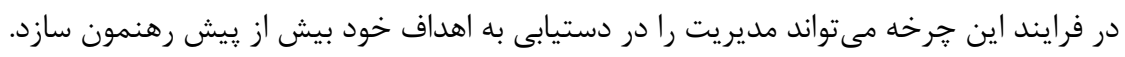
از دلايل اقتصادى كه مشاركت كنندكان در يزوهش به به عنوان شرايط علّى نياز به افزايش صلاحيت و شايستخى مديران حسابرسى داخلى و به تبع آن نياز به حسابرسى داخلى با كيفيت ذكر نمودند، نياز به افزايش محتواى اطلاعاتى خروجى هاى سيستم مالى و حسابدارى است تاني

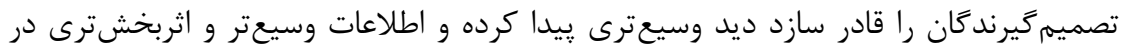
مورد نتايج عملكردها داشته باشند و در سطح كلان منتج به رشد و توسعه اقتصادى گردد. به علاوه، اجتناب از بحرانهاى مالى، مبارزه با فساد و يولشويى و جذب صحيح ماليات از جمله دلايل سياسى على ذكر شده است. همجنين، عواملى مانند شفافيت و ياسخكويى، افزايش سطح نيازها و انتظارات و آحاهى و عدم تحقق مكرر برنامهها و اهدف تعيين شده براى سازمان نيز از جمله عواملى هستند كه در يروهش حاضر به عنوان شرايط علّى محيطى استخراج شده است. به 
عنوان مثال، مصاحبه شوندكان بيان داشتند كه افزايش سطح نياز و آكاهى سرمايه كذاران به

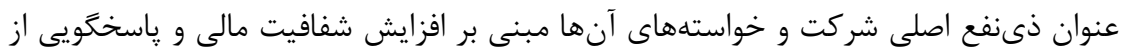

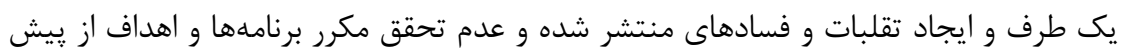
تعيين شده براى سازمانها و شركتها از طرف ديكر، باعث ترديد تا اراده واحدى در تمام ابعاد

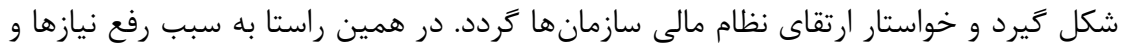

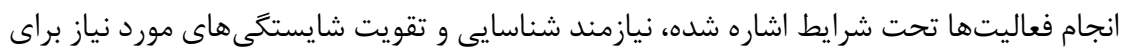

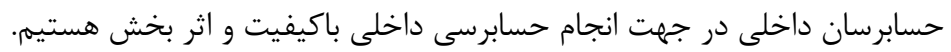

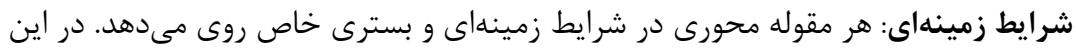

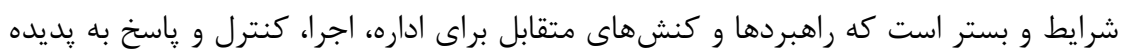

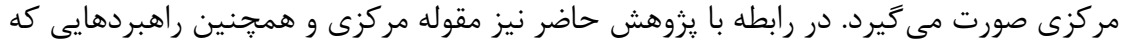

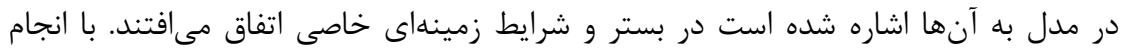

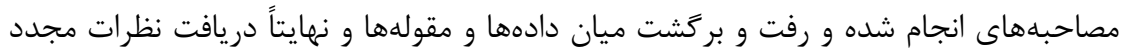

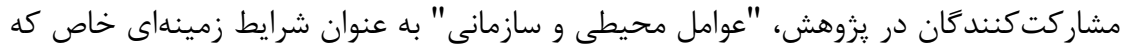

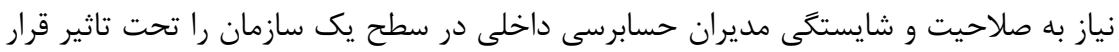

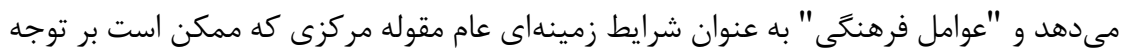
و تقويت ابعاد شايستكى مديران حسابرسان داخلى كليه شركتهاى ايرانى اثر كذار بوده و واغلب خارج از كنترل آنها مى باشد تعيين كرديد.

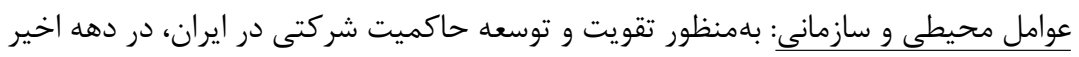

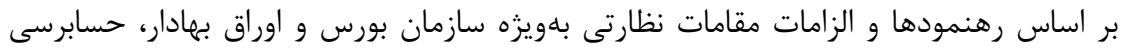
داخلى نوين در ايران در كانون توجه قراركرفته است. ليكن همانكونه كه تشريح شد حرفات دانه

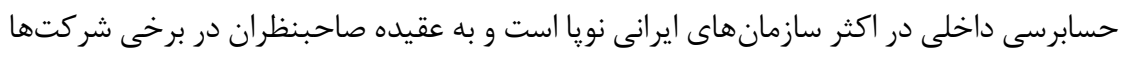

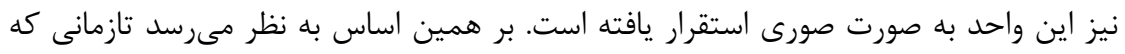

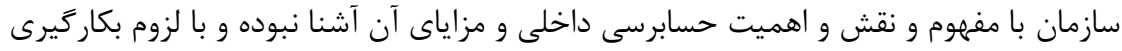

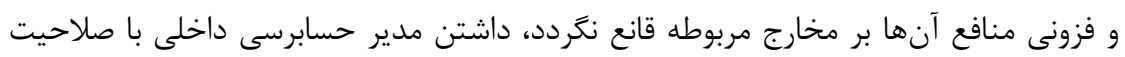

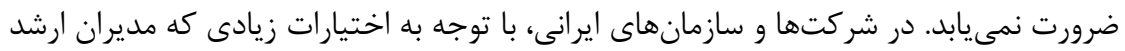

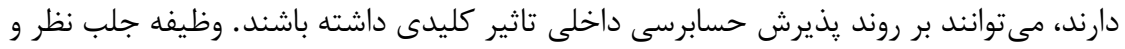

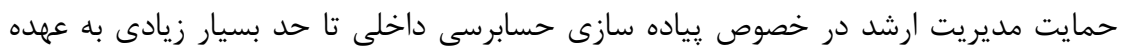

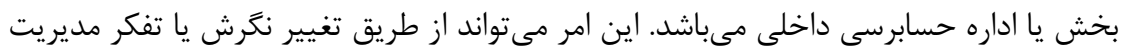

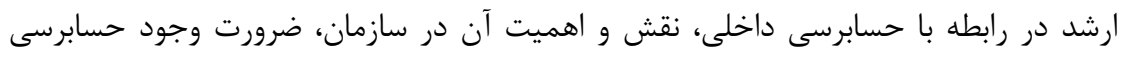


داخلى به صورت كلى، مزايا و فوايد حسابرسى داخلى صورت يذيرد(باقريور ولاشانى و همكاران،

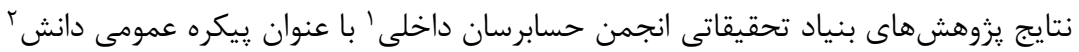

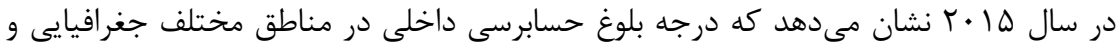

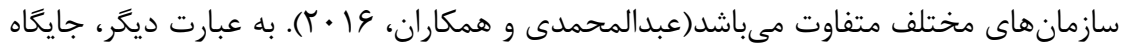
حرفه حسابرسى داخلى در كشور و ميزان توسعه و يُيشرفت آن، از عوامل بسترى مهرم مدل شايستخى مديران حسابرسى داخلى است. ميزان سابقه حرفه حسابرسى داخلى در كشور و نظارت

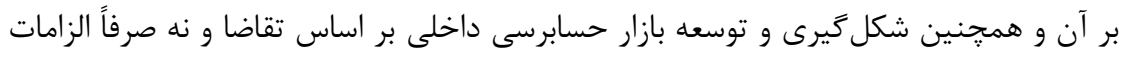

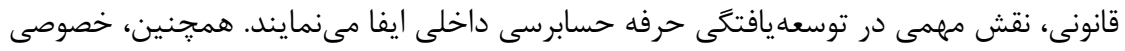

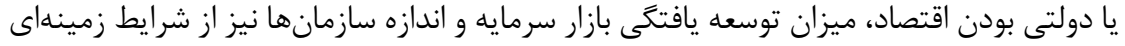

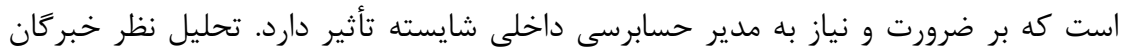

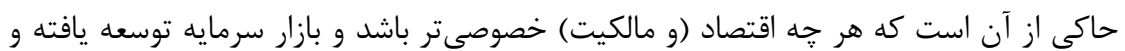
ساختار يافته باشد، تقاضا براى كيفيت حسابرسى داخلى و به تبع آن آن نياز به مديران آنان شايسته

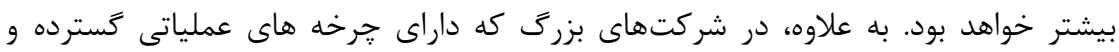

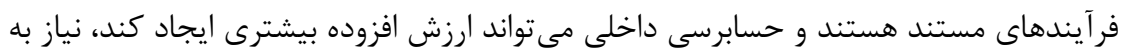
مديران متخصص و با صلاحيت بيشتر احساس خواهد شد. در اين يزوهش جنبههاى مختلف راهبرى شركتى از قبيل ويزگى هاى هيئت مديره، محيط احتيط

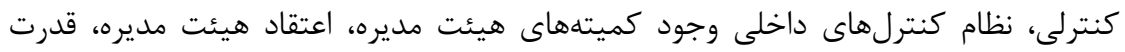
سازوكارهاى راهبرى شركت و نيز وضعيت نظارت نهادهاى ناظر، قوانين، بخشنامهها،

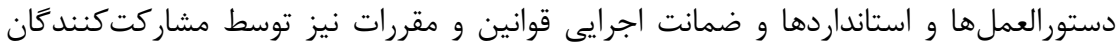

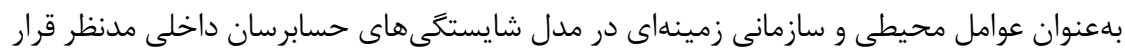
كرفتهاند. برخى از مشاركت كنندًان در يزوهش بيان و و تاكيد نمودان

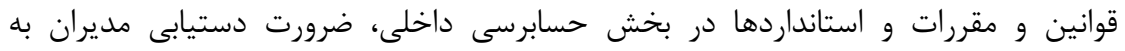

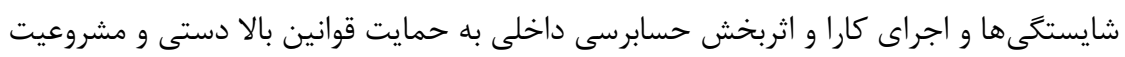

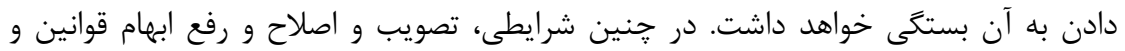

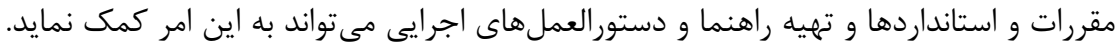

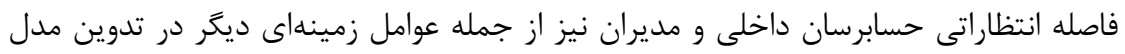

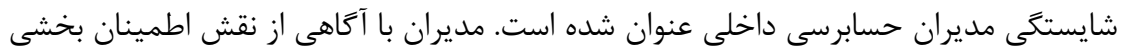


و مشاورهاى حسابرسان داخلى، ضمن أَاهى بيشتر از نقش حياتى حسابرسان داخلى در سازمان،

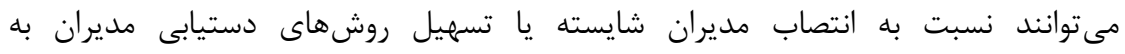
شايستكى هاى لازم متناسب با تغييرات روزمره در نقش آنان كام بان بردارندان

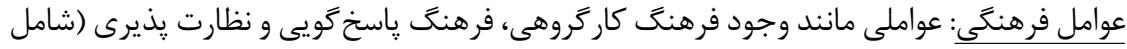

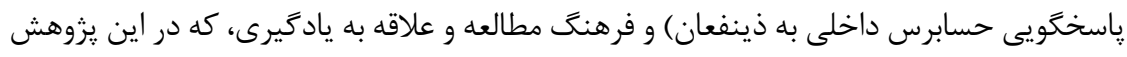

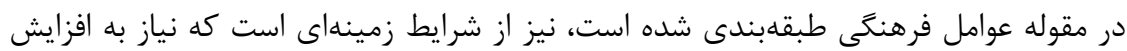

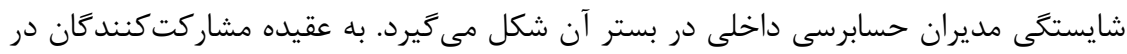

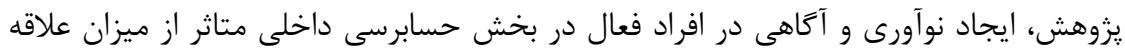

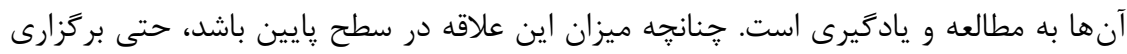

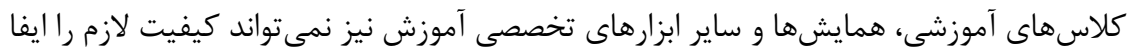

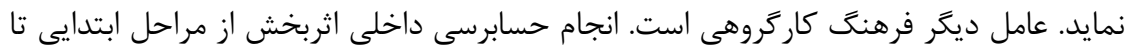

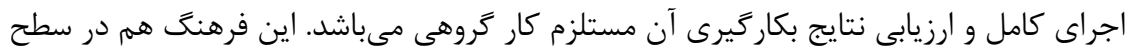
كلان و هم در سطح خرد بايد وجود داشته باشد.

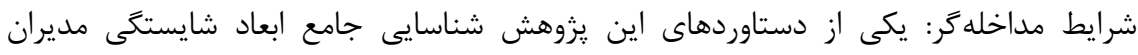

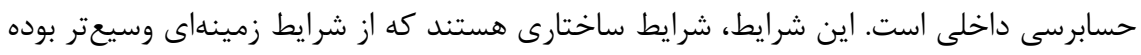

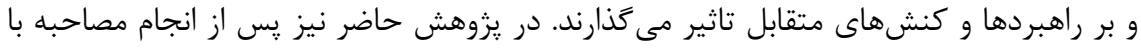

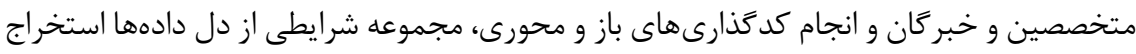

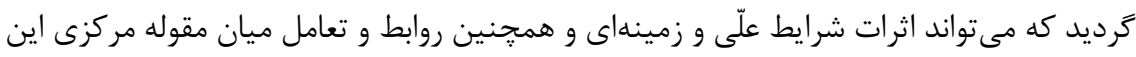

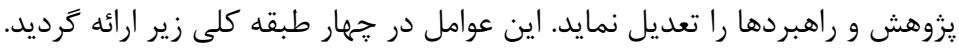

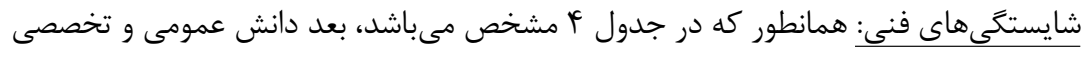

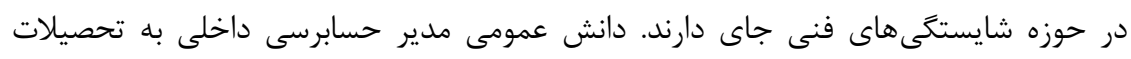

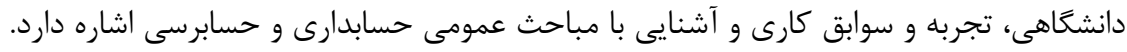

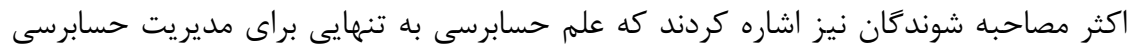

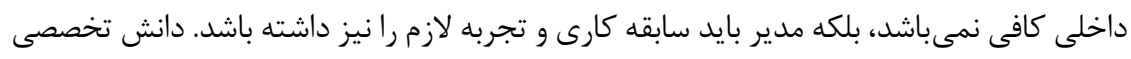

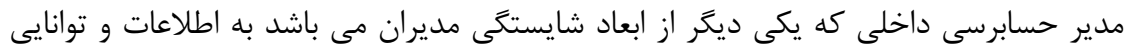

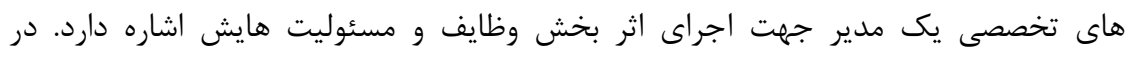

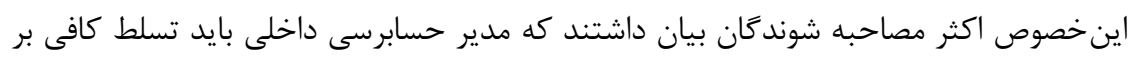

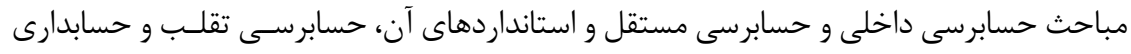

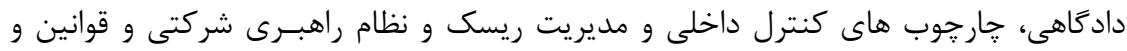

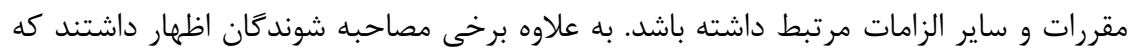


يك مدير حسابرسى داخلى موفق بايد آشنايى يا تسلط بر مباحث فناورى اطلاعات، زبان انخليسى

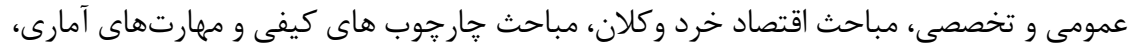
نرم افزارى و تحليلى داشته باشد.

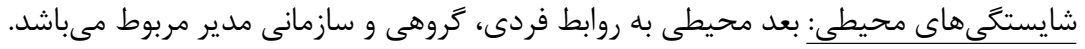

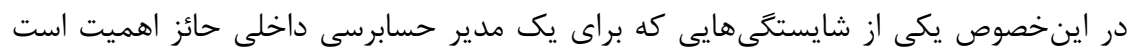

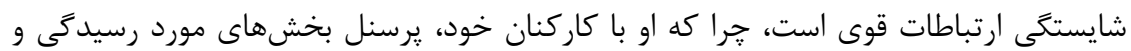
كميتهها و مديران بالادست داراى تعامل و ارتباط است. لذا اكثر مصاحبه شوندكان بيان داشتيند

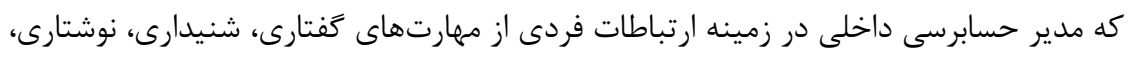

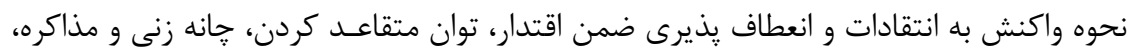

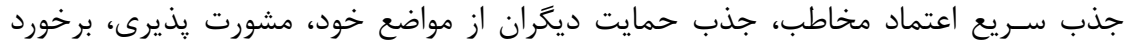

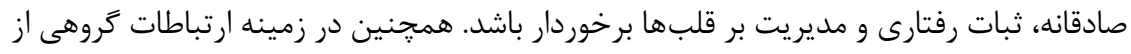

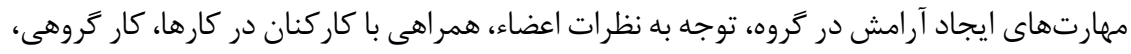

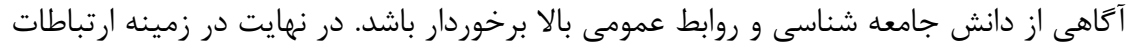

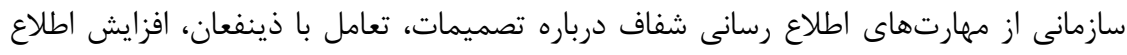

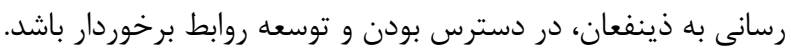

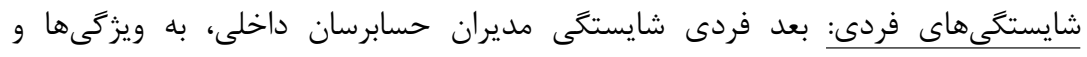

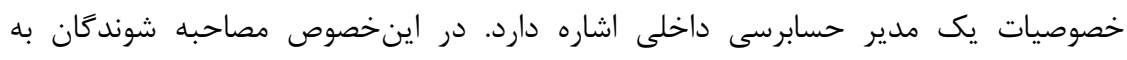

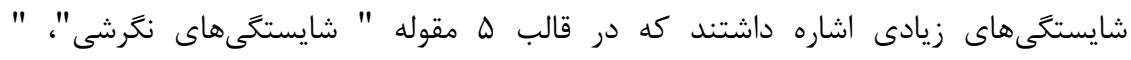

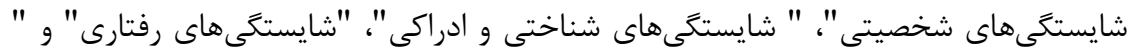

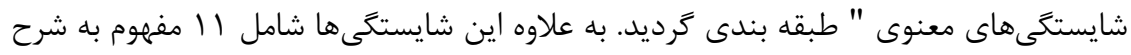

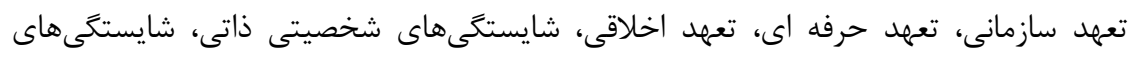

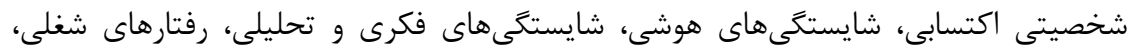

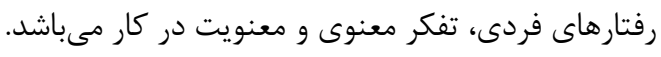

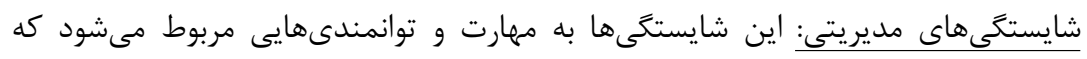

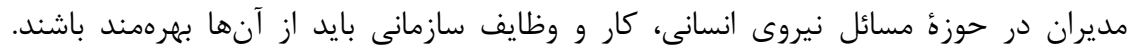

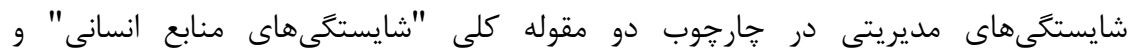

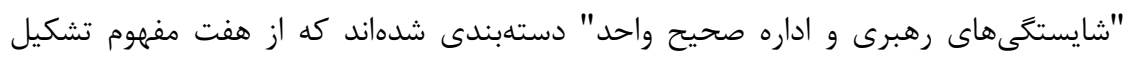

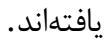
در اين يزوهش، اكثر مشاركت كنندكان به اهميت بالاى توجه به منابع انسانى اشاره داشته

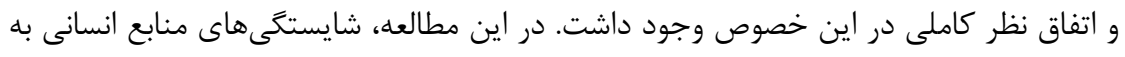


اين دليل به عنوان يك مقوله مجزا و در قالب شايستگىهاى مديريتى قرار گرفتهاند كه اولا،

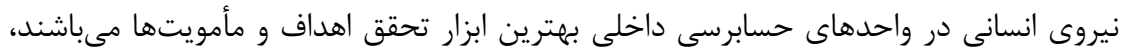

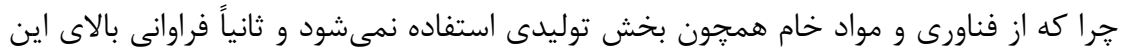

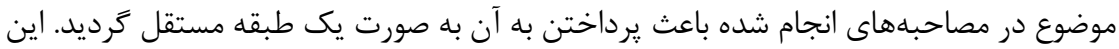

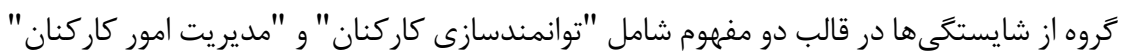

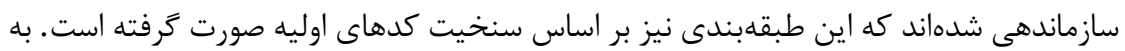

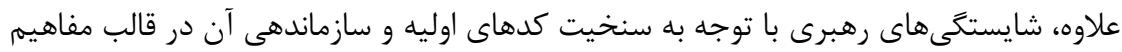

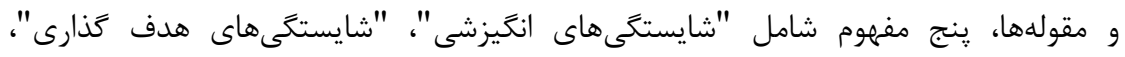

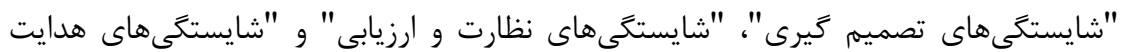

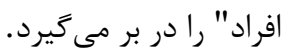
جدول fا: فهرست طبقات، مقوله ها و مفاهيم اصلى ناشى از كدكذارى محورى عوامل مداخله كر

\begin{tabular}{|c|c|c|}
\hline 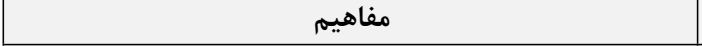 & مقوله ها & طبقه \\
\hline 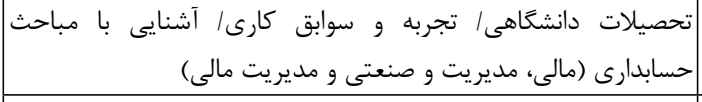 & 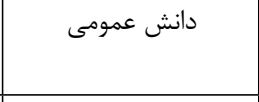 & \multirow[t]{2}{*}{ فنى ايستى هاى } \\
\hline 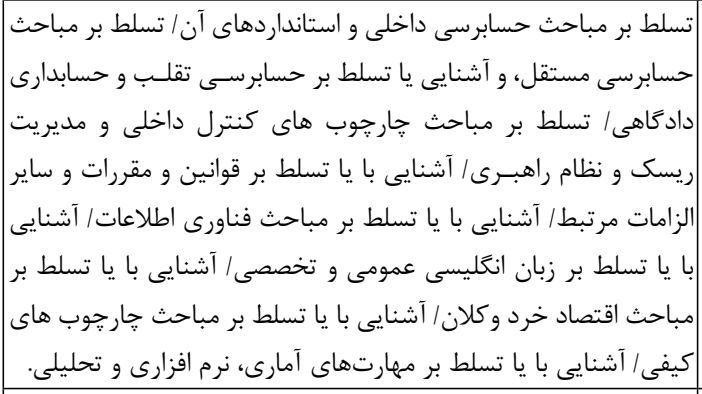 & دانش تخصصى & \\
\hline 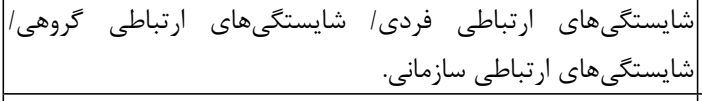 & شايستخى هاى تعاملى و & شحيطى شايستى هاى \\
\hline |توانمندسازى كاركنان/مديريت امور كاركنان. & مديريت منابع انسانى & \multirow{2}{*}{ مديريتى } \\
\hline 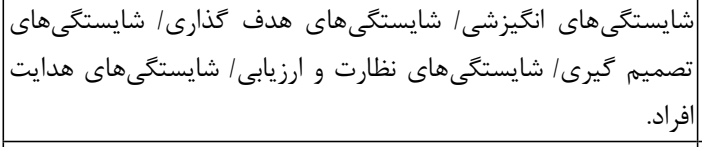 & |شايستخى رهبرى و اداره & \\
\hline |تعهد سازمانى/ تعهد حرفه اى/ تعهد اخلاقى. & شايستخى هاى نخرشى & \multirow{5}{*}{ فردى شايستى هاى } \\
\hline |شايستكى هاى شخصيتى ذاتى/ شايستًى هاى شخصيتى اكتسابى. & شايستكى هاى شخصيتى & \\
\hline شايستخى هاى هوشى/ شايستخى هاى فكرى و تحليلى. & | شايستخى هاى شناختى & \\
\hline |رفتارهاى شغلى/ رفتار هاى فردى. & شايستخى هاى رفتارى & \\
\hline 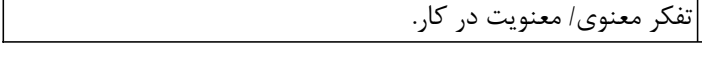 & شايستخى هاى معنوى & \\
\hline
\end{tabular}




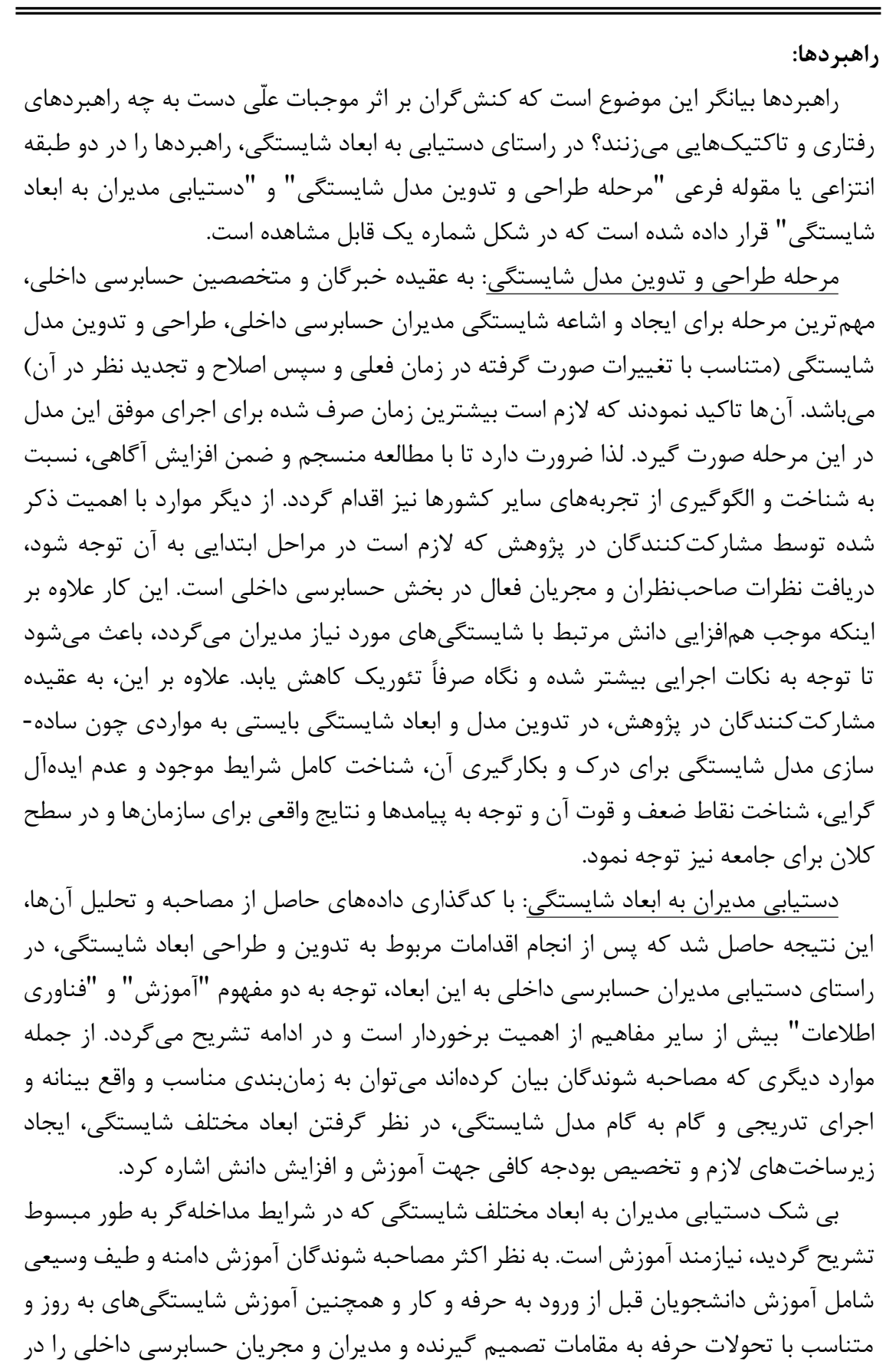


بر مى گيرد. با توجه به گستردگى مفاهيم بيان شده، در يزوهش حاضر آموزش در سه بخش

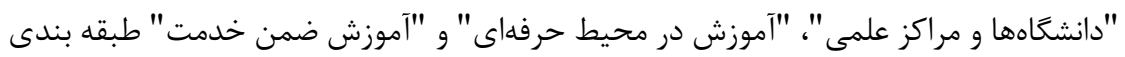

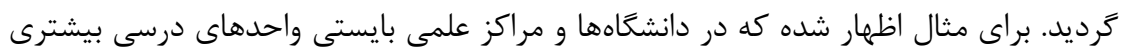
به مباحث تخصصى ماند حسابرسى داخلى، راهبرى شركتى، كنترلهاى داخلى و مدائى مديريت

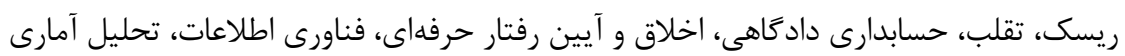

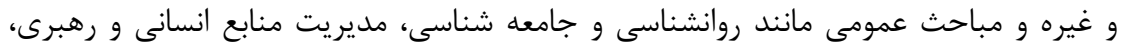
فنون مذاكره و ارتباطات، تفكر انتقادى و غيره تخصيص داده شود؛ و يا در مقطع كارشناسى ارشد ماند

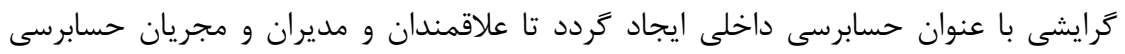

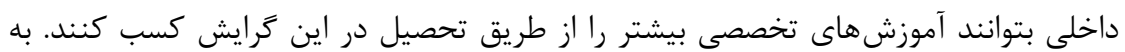

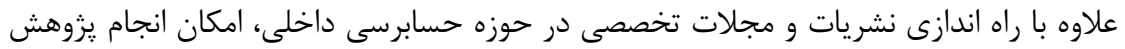

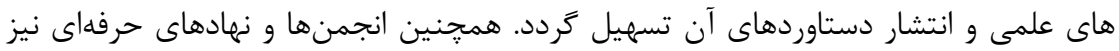

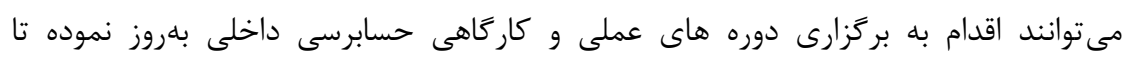

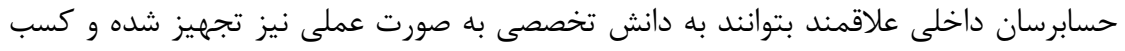

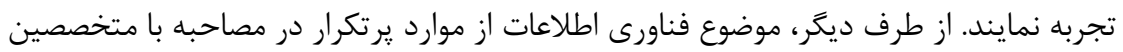

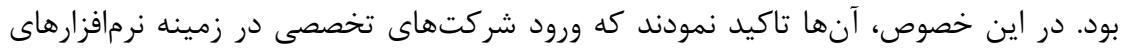

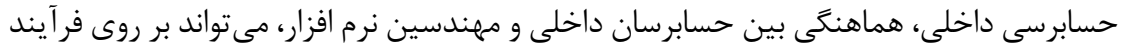

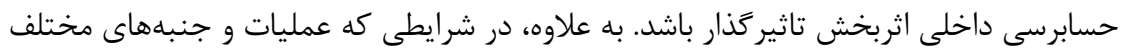

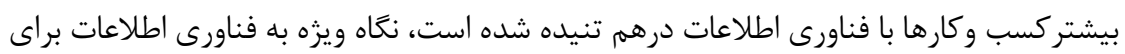

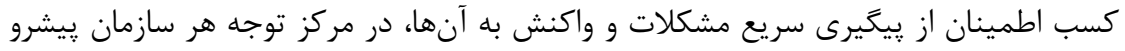

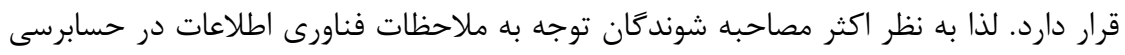

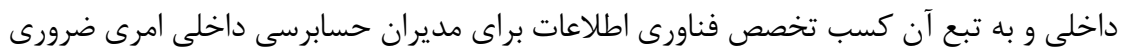

يبامدها: هر جا انجام يا عدم انجام عمل معينى در ياسخ به امر يا مسالداى يا به منظور اداره

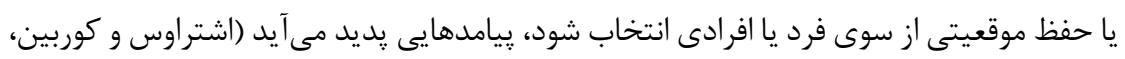

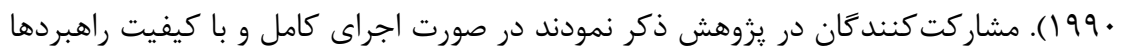

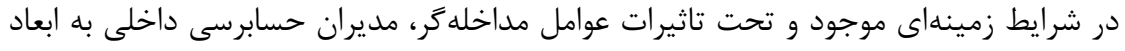

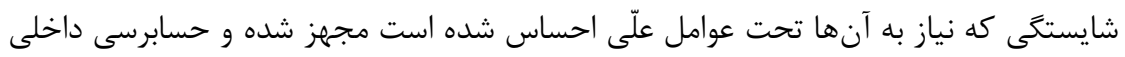
به اهداف از ييش تعيين شده خود دست خواهد يافت. آنها تاكيد نمودند بكاركيرى مدير إيران حسابرسى داخلى شايسته و با صلاحيت منجر به اجراى حسابرسى داخلى اثربخش و باكيتيفيت

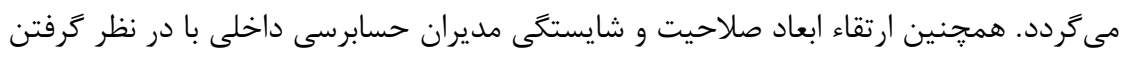




\begin{tabular}{|c|c|c|c|}
\hline \multicolumn{4}{|c|}{ 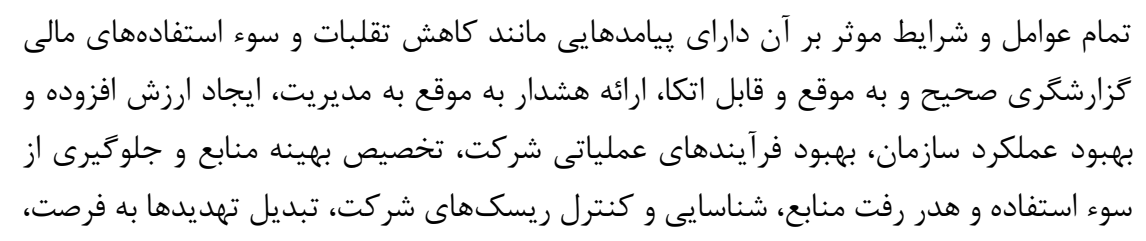 } \\
\hline \multicolumn{4}{|c|}{ در اين يزوهش براى اعتباربخشى به مدل و نتايج در بخش كيفى يزوهش از زاويلبندى يا } \\
\hline \multicolumn{4}{|c|}{ مثلث بندى، كنترل اعضا و ارزيابى بر اساس معيار مقبوليت استفاده شد و تلاش گرديد معرد تمام } \\
\hline \multicolumn{4}{|c|}{ • يافتههاى بخش مربوط به اين معيارها برآورده شود. } \\
\hline \multirow{2}{*}{\multicolumn{4}{|c|}{ جدايج به دست آمده در رابطه با آزمون فريدمن به تفكيك شركتهاى بزرگ، متوسط و كوجى د د }} \\
\hline & & & \\
\hline \multicolumn{4}{|c|}{ جدول ه: نتايج آزمون فريدمن } \\
\hline & شركتهاى بزرى & 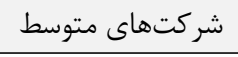 & شركتهاى كوجى \\
\hline تعداد مشاهدات (N) & $|4|$ & $|f|$ & $|f|$ \\
\hline آماره خي دو (Chi-Square) & $19 \cdot 9.9$ & IVTI.9 & IVQY.9 \\
\hline درجه آزادى (d) & Tr & Tr & rT \\
\hline سطح معنى دارى (Asymo. Sig) & & & \\
\hline
\end{tabular}




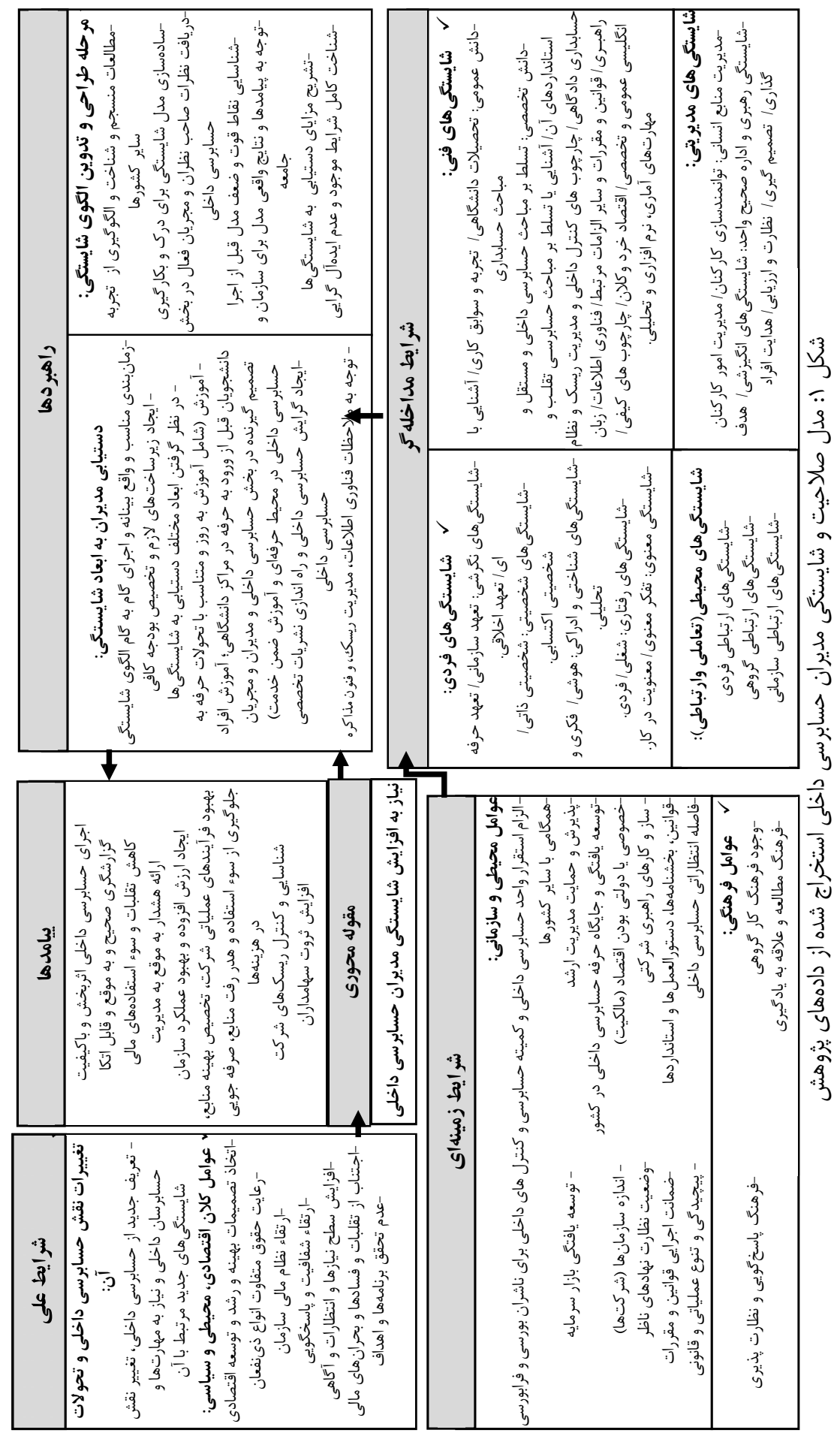


با توجه به اينكه سطح معنى دارى اين آزمون كمتر از ه درصد است، فرضيه صفر مبنى بر يكسان

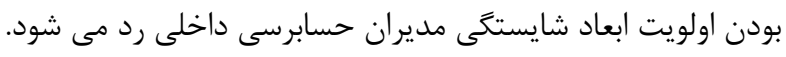

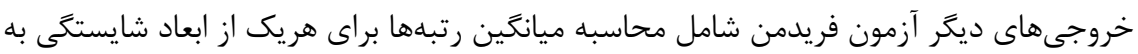

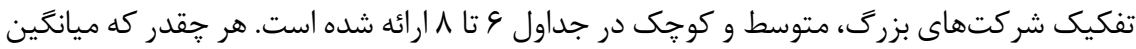

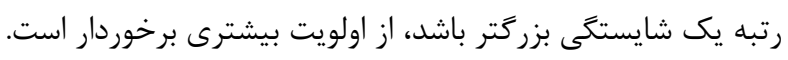

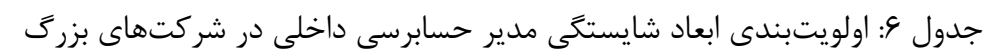

\begin{tabular}{|c|c|c|c|c|c|}
\hline ميانگين & متغير & 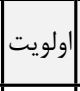 & ميانگين & متغير & 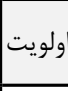 \\
\hline IQ.VF & شايستخىىهاى هدايت افراد & 11 & TV.T. & تجربه و سوابق كارى & 1 \\
\hline $10.9 V$ & تقلـب و حسابدسى مستقل، حسابرسى دادَاهى & 19 & r9.1V & حسابرسى داخلى و استانداردهاى & r \\
\hline $10.4 F$ & توانمندسازى كاركنان & $r$. & $r 9 \cdot 0$ & تحصيلات دانشخاهى & r \\
\hline $10 . f^{c}$ & شايستكى هاى تصميم گيرى & Y) & rM.AV & شايستگى هاى فكرى و تحليلى & f \\
\hline ID.TF & شايستخى هاى شخصيتى ذاتى & tr & rr.Vr & مديريت ريسك هار و نظام رنترل داخلى و & $\Delta$ \\
\hline 10.9 & شايستكى هاى نظارت و ارزيابى & r & $r 1.99$ & قوانين و مقررات و ساير الزامات & 9 \\
\hline$|f . Y|$ & مديريت امور كاركنان & TF & $Y|| F \mid$. & فناورى اطلاعات & V \\
\hline $1 f .1 \mathrm{~V}$ & شايستخى هاى شخصيتى & $r \Delta$ & $r I \cdot \Delta$ & تعهد اخلاقى & $\wedge$ \\
\hline Ir.Ve & شايستتى هاى هوشى & rq & $r \cdot . v q$ & تعهد حرفه اي & 9 \\
\hline $1 \% . \wedge 9$ & مهارتهاى آمارى، نرم افزارى و & tr & $1 \wedge .19$ & شايستخىى هاى ارتباطى سازمانى & $1 \cdot$ \\
\hline IT.VG & شايستخى هاى هدف گذارى & rA & $1 \Lambda . \cdot V$ & حسابدارى (مالى، مديريت و مديتى مالى & 11 \\
\hline Itr.tA & شايستخى هاى انگيزشى & rq & IV.VV & شايستكى هاى ارتباطى فردى & it \\
\hline IT.TG & زبان انخليسى عمومى و تخصصى & r. & IV.D. & جارجوب هاى كيفى & Ir \\
\hline $1 \cdot . \mathrm{KT}$ & اقتصاد خرد وكلان & r & IV.IT & رفتارهاى شغلى & If \\
\hline V.94 & تفكر معنوى & rt & $19.9 \cdot$ & شايستخى هاى ارتباطى گروهى & 10 \\
\hline \multirow[t]{2}{*}{9.09} & معنويت در كار & r & $19 . V \cdot$ & رفتارهاى فردى & 19 \\
\hline & & & $19 . \Delta T$ & تعهد سازمانى & IV \\
\hline
\end{tabular}



دكتر وديعى و همكاران، طراحى مدل و اولويتبندى ابعاد شايستكى مديران حسابرسى داخلى...

\begin{tabular}{|c|c|c|c|c|c|}
\hline \multicolumn{6}{|c|}{ جدول V: اولويتبندى ابعاد شايستخى مدير حسابرسى داخلى در شركتهاى متوسط } \\
\hline ميانگين & 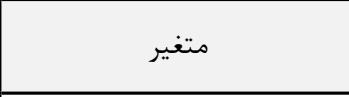 & 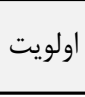 & ميانخين & 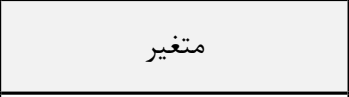 & اولويت \\
\hline 19.9. & حسابرسى مستقل، حسابرسـى حسابدارى داد حاهى & 11 & rV.A. & تجربه و سوابق كارى & 1 \\
\hline $19 . \Delta r$ & شايستخى هاى نظارت و ارزيابى & 19 & TV. $.9 \wedge$ & حسابرسى داخلى و و آنداردهاى آن & r \\
\hline 10.90 & شايستخى هاى شخصيتى ذاتى & $r \cdot$ & r9.91 & تحصيلات دانشگاهى & r \\
\hline $\mid 0.91$ & مديريت امور كاركنان & TI & rt.9I & قوانين و مقررات و ساير & f \\
\hline 10.49 & شايستخى هاى ارتباطى گروهى & tr & $r r . \cdot q$ & تعهد حرفه اى & $\Delta$ \\
\hline $10.1 T$ & فناورى اطلاعات & r & $r r^{\prime} \cdot r$ & تعهد اخلاقى & 4 \\
\hline $10 \cdot \cdot \theta$ & جار جوب هاى كيفى & TF & rI.1T & 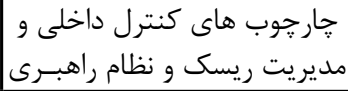 & V \\
\hline If.AT & شايستخى هاى هوشى & $r \omega$ & 19.19 & شايستخى هاى فكرى و تحليلى | & $\wedge$ \\
\hline $14 . g r$ & شايستگى هاى شخصيتى & rद & $19 . r \Delta$ & مديريت و صنعتى و مسابدارى (مالى، مديريت & 9 \\
\hline $1 r .9$. & شايستخى هاى هدف گذارى & tr & 19.rr & رفتارهاى فردى & 1 . \\
\hline $1 T .9$ & شايستگى هاى انخيزشى & rA & 19.rT & رفتارهاى شغلى & 11 \\
\hline 11.9 & زبان انخليسى عمومى و & rq & $1 \wedge . \vee \Delta$ & شايستكى هاى ارتباطى فردى & it \\
\hline $9.1 \wedge$ & تفكر معنوى & r. & $11 \cdot \cdot V$ & تعهد سازمانى & Ir \\
\hline$\wedge . \Delta \wedge$ & اقتصاد خرد وكلان & r & IV.r. & شايستخى هاى ارتباطى سازمانى & if \\
\hline V.VT & معنويت در كار & rt & $19 . \wedge \mathrm{V}$ & شايستخى هاى تصميم گيرى & 10 \\
\hline \multirow[t]{2}{*}{ V.DT } & مهارتهاى آمارى، نرم افزارى و & r & $19.9 \mathrm{~V}$ & شايستكَىهاى هدايت افراد & 19 \\
\hline & & & 19.94 & توانمندسازى كاركنان & IV \\
\hline
\end{tabular}


دو فصلنامه حسابدارى ارزشى و رفتارى، سال ينجه، شماره نهم، بهار و تابستانو9؟1

\begin{tabular}{|c|c|c|c|c|c|}
\hline \multicolumn{6}{|c|}{ جدول ^: اولويتبندى ابعاد شايستخى مدير حسابرسى داخلى در شركتهاى كوجى } \\
\hline ميانگين & متغير & اولويت & ميانگين & متغير & اولويت \\
\hline $19.1 \mathrm{~F}$ & شايستخى هاى ارتباطى & 11 & TV.FF & تجربه و سوابق كارى & 1 \\
\hline $10 . T \cdot$ & شايستخى هاى ارتباطى & 19 & TG.DT & تحصيلات دانشعاهى & $r$ \\
\hline If.VG & شايستخى هاى شخصيتى & $r \cdot$ & rD.DF & استانداردهاى داخى آنى و & r \\
\hline $\mid f . \Delta f$ & شايستخى هاى هدف & rl & TY.DF & تعهد اخلاقى & f \\
\hline 11.49 & شايستخى هاى انخيزشى & rt & TF.19 & تعهد حرفه اي & $\Delta$ \\
\hline IT.rV & شايستخى هاى هدايت افراد & r & TY.DT & مباحث حسابدارى (مالى، مديريت و صنعتى و مدير مالى) & 4 \\
\hline מז.ru & مديريت امور كاركنان & rF & $r t . \cdots$ & 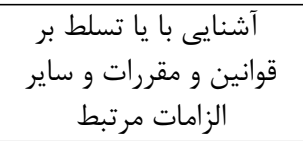 & V \\
\hline $11 . \cdot 9$ & شايستگى هاى نظارت و ارزيابى & ra & TI... & شايستخى هاى ارتباطى & $\wedge$ \\
\hline $1 T .94$ & توانمندسازى كاركنان & rq & ri.t. & شايستخى هاى تصميم & 9 \\
\hline IT.YF & زبان انخليسى عمومى و & rV & $r \cdot r \cdot$ & رفتارهاى فردى & $1 \cdot$ \\
\hline 11.90 & تفكر معنوى & $r \Lambda$ & 19.11 & رفتارهاى شغلى & 11 \\
\hline 11.11 & فناورى اطلاعات & rq & 19.rV & شايستكى ذاى شخصيتى & it \\
\hline $1 \cdot . r 1$ & معنويت در كار & $r \cdot$ & $11.1 \mathrm{~F}$ & تعهد سازمانى & 14 \\
\hline 9.91 & جار جوب هاى كيفى & r & $1 \Lambda .1 \%$ & شايستخى هاى هوشى & If \\
\hline V.A. & اقتصاد خرد وكلان & rt & $1 \wedge \cdot \Delta$ & شايستكى هاى فكرى و & 10 \\
\hline \multirow[t]{2}{*}{$9 . \wedge \Delta$} & مهارتهاى آمارى، نرم & س & $\mid V .91$ & داخلى و هدوب هاريت كنترل ريسك و & 19 \\
\hline & & & 19.11 & حسابرسى مستقل، و & IV \\
\hline
\end{tabular}


بر اساس نتايج حاصله مشاهده مىشود كه سه مولفه تجربه و سوابق كارى، تحصيلات

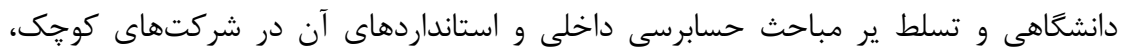

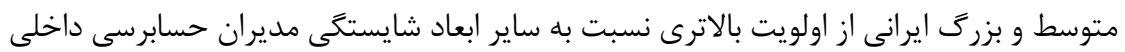
برخوردارند. به علاوه در شركتهاى بزرى، شايستخى هاى فكرى و تحليلى، تسلط بر مبر مباحث

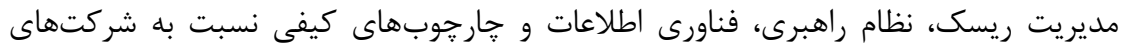

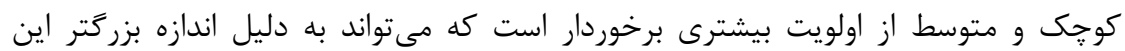

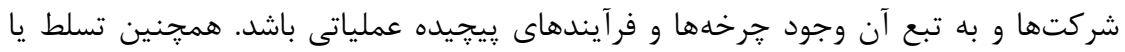

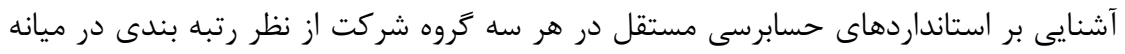

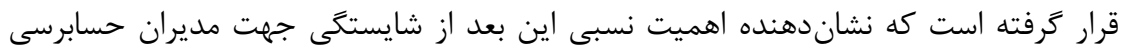

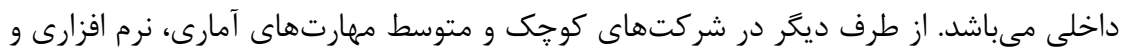

$$
\text { تحليلى در اولويت آخر قرار دارد. }
$$

در ادامه از ميانگين رتبه شايستخىهاى هر يكى از دستهها ميانگين كيرى به عمل آمد كه

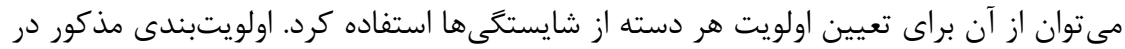

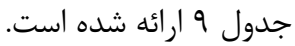

\begin{tabular}{|c|c|c|c|c|c|c|c|}
\hline \multicolumn{2}{|c|}{ شركتهاى كوجى } & \multicolumn{2}{|c|}{ | شركتهاى متوسط | } & \multicolumn{2}{|c|}{ شركتهاى بزرى } & \multirow{2}{*}{ شايستخى } & \multirow[b]{2}{*}{ دسته } \\
\hline اولويت & ميانكين & ولويت & ميانگين رتبه & اولويت & ميانگين رتبه & & \\
\hline 1 & $r \cdot .$. & 1 & $r \cdot r \Delta$ & 1 & $r \cdot . \Lambda V$ & IT & شايستخى هاى فنى \\
\hline$r$ & $1 V .94$ & $r$ & IV.T. & $r$ & $1 V .9 \Lambda$ & $r$ & شايستخى هاى محيطى \\
\hline$r$ & IV.VI & $r$ & $19 . \pi \%$ & $r$ & $10 . F^{k T}$ & 11 & شايستخى هاى فردى \\
\hline f & $14 . V \wedge$ & r & 10.09 & F & $1 f . \Delta \Lambda$ & V & شايستخى هاى مديريتى \\
\hline
\end{tabular}

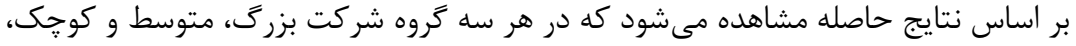

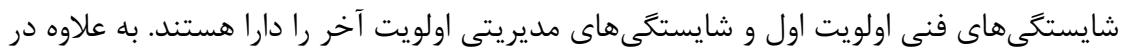
شركتهاى بزرك ميانكين رتبه شايستگى هاى فنى و محيطى از شركتهاى متوسط و و كوجى بيشتر است. به عبارت ديكر دستيابى مديران حسابرسى داخلى در شركتئي

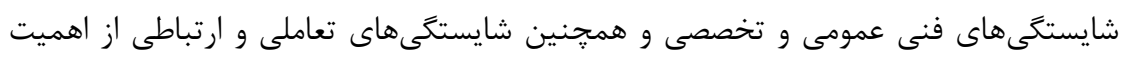

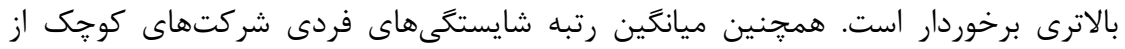
شركتهاى بزرى و متوسط بيشتر است كه نشاندهنده اهميت بالاى شايستكى هاى نكرشى، شخصيتى، شناختى و ادراكى، رفتارى و معنوى در شركتهاى كو جنى است. 


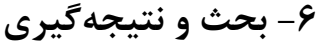

به دليل عدم انجام يزوهش در زمينه تدوين مدل صلاحيت و شايستگى در ارتباط با

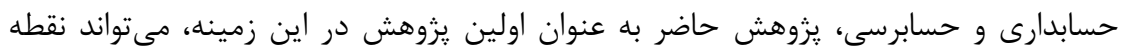

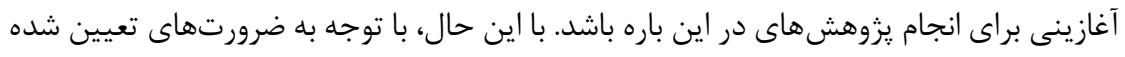

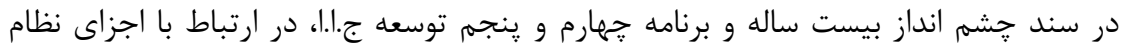

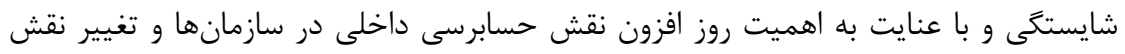

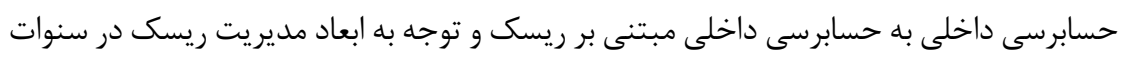

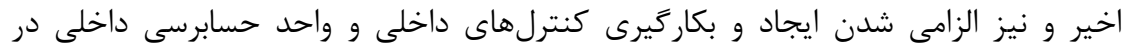

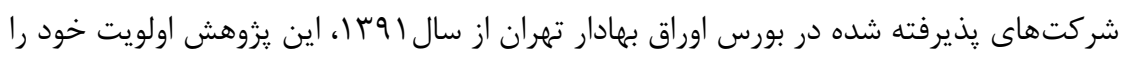

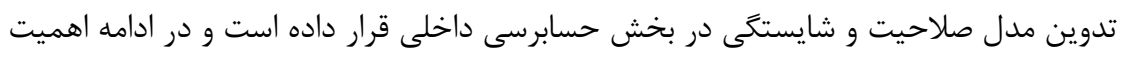

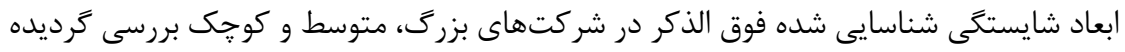

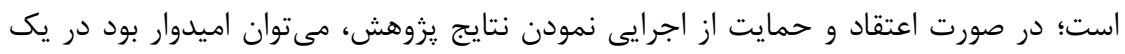

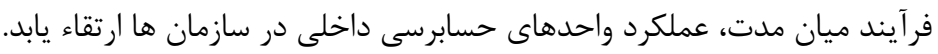

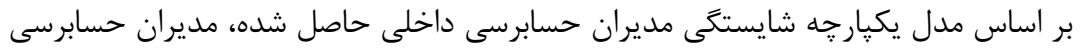

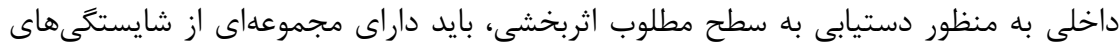

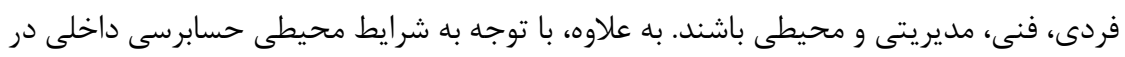

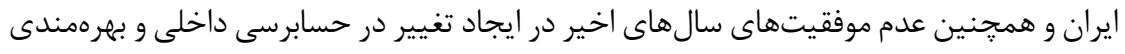

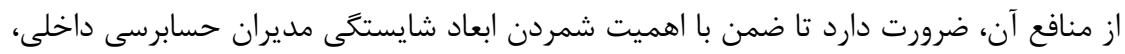

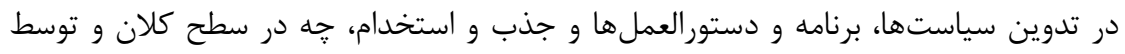

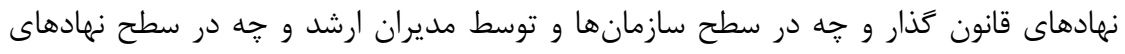

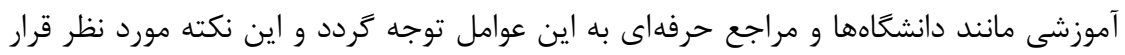

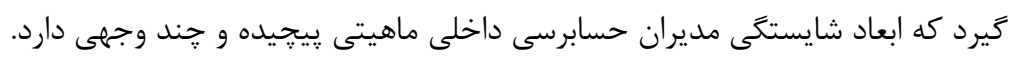

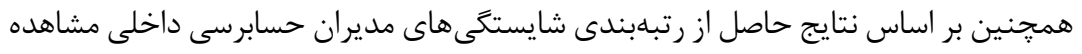

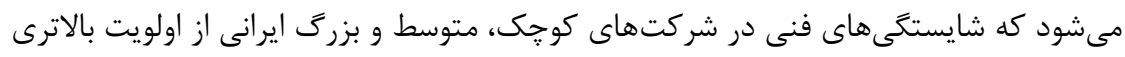

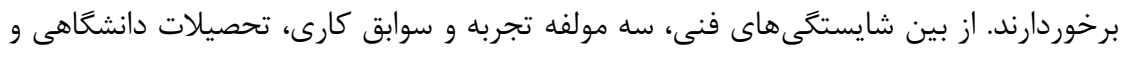

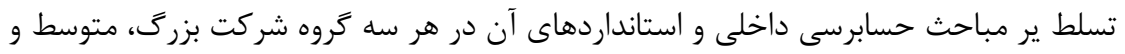

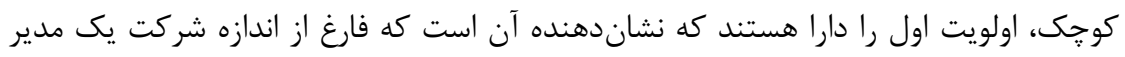

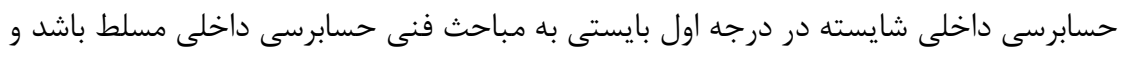

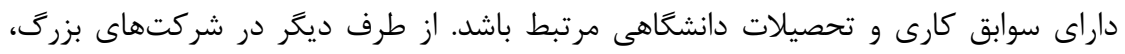


شايستگى هاى فكرى و تحليلى، تسلط بر مباحث مديريت ريسك، نظام راهبرى، فناورى اطلاعات

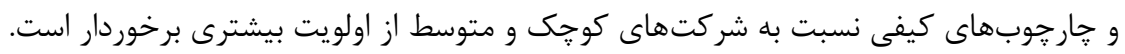

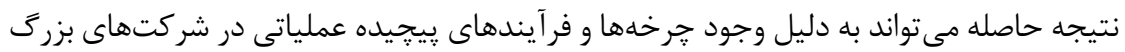

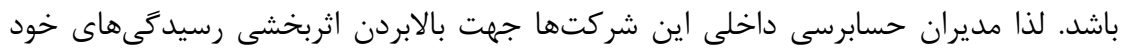

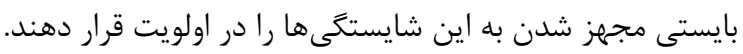

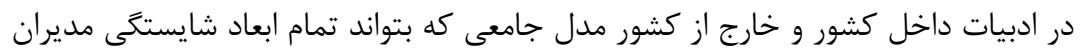
حسابرسى داخلى را بررسى كند وجود ندارد. در نتيجه برخى از مولفهها و عوامل تعيين شده كه

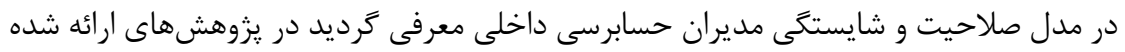

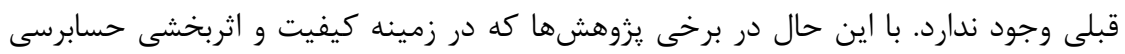

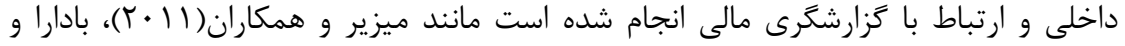

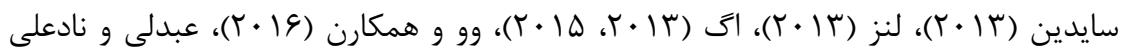

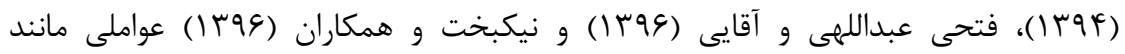
مهارتهاى فنى، تحصيلات، تجربه، آموزش، كواهينامه حرفهاى (مدركى حسابدار رسمى)، اخلاق

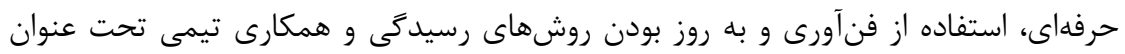

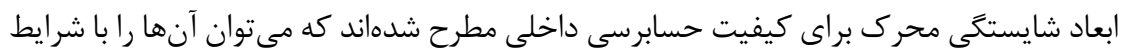

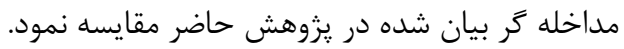

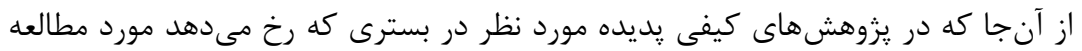

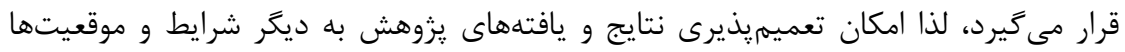

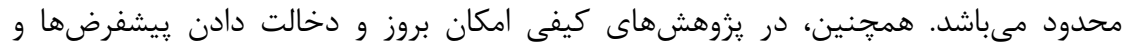

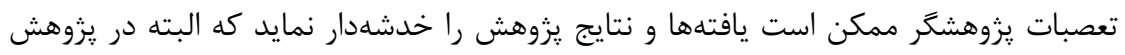

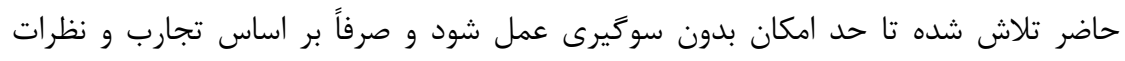

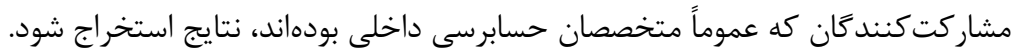

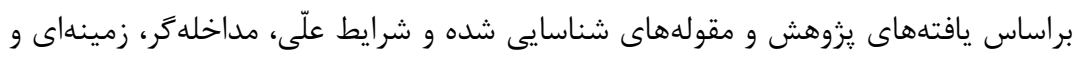

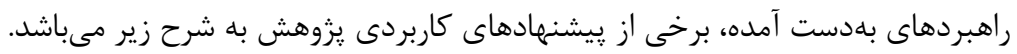

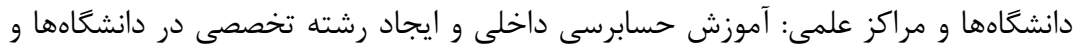

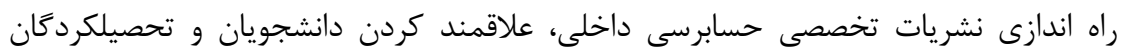

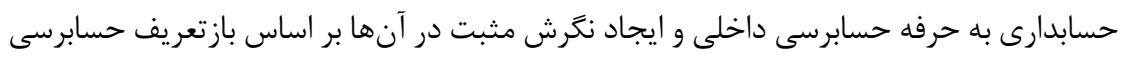

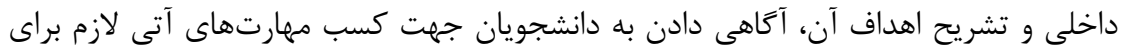

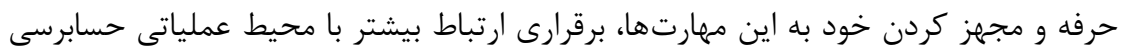

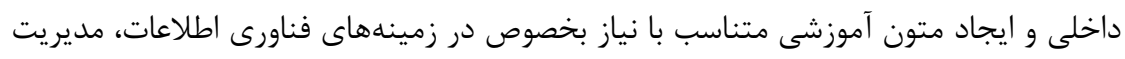


ريسك، فنون مذاكره، جامعه شناسى و روانشناسى، تقلب، حاكميت شركتى و غيره، بركزارى همايشها و ايجاد رسانههاى تخصصى در اين ائن رابطه.

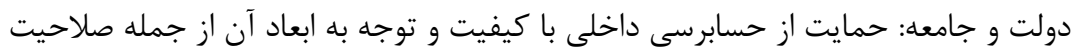

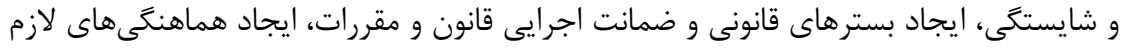

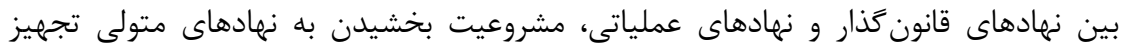

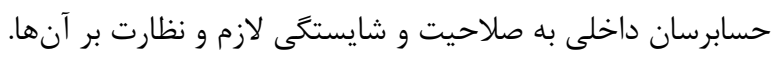

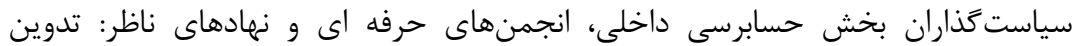

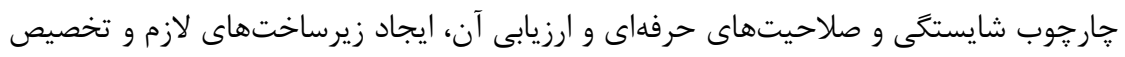

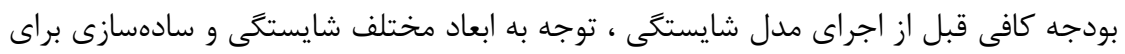

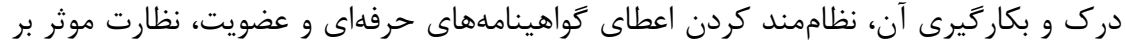
كيفيت واحدهاى حسابرسى و اعضاء، تدوين و انتشار رهنمودها و نشريات حرفه ائ نـائ

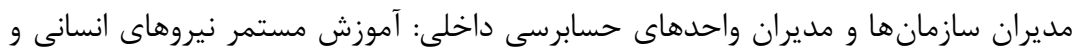

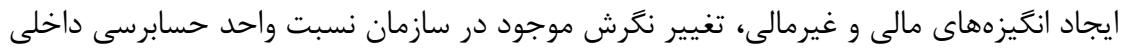
و دستيابى يرسنل به ابعاد شايستكى در جهت انجام حسابرسى داخلى اثر بخش، حمايت كامل

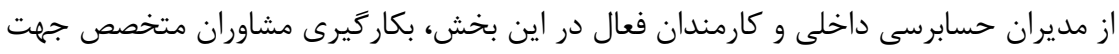
ياسخكويى به سوالات كاركنان.

\section{V- تقدير، تشكر و ملاحظه هاى اخلاقى}

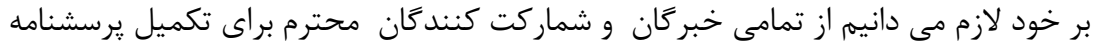

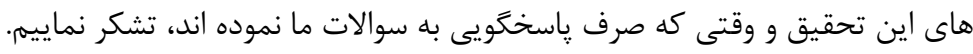

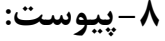

ير سشنامه در بخش كمى مئ

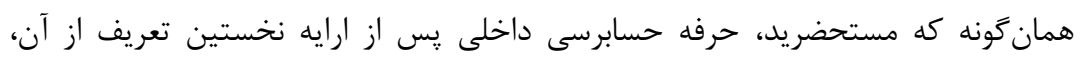

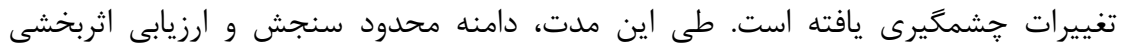

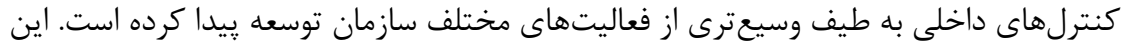

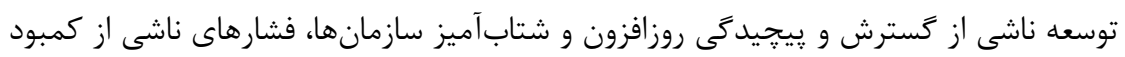

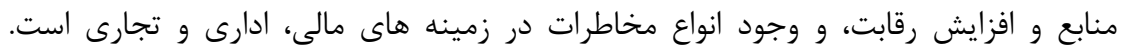

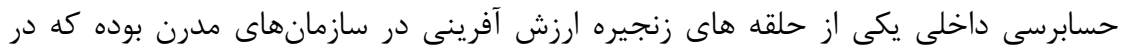


جارجوب نظام راهبرى شركتى نقش مهمى در توسعه يايدار شركت ايفا مى كند. بديهى است كه

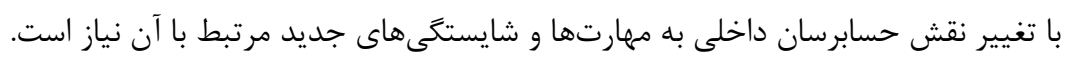

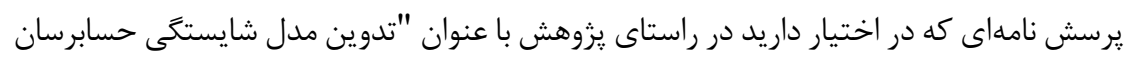

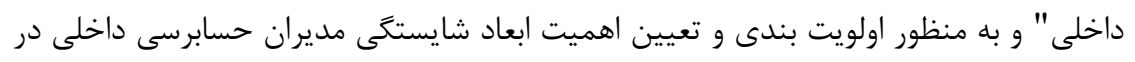

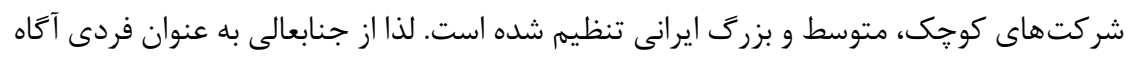

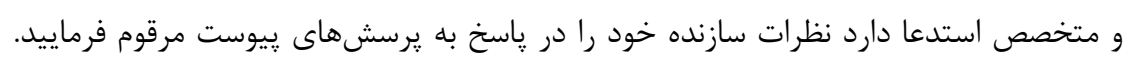

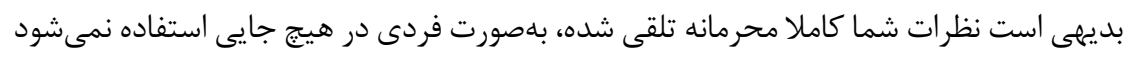

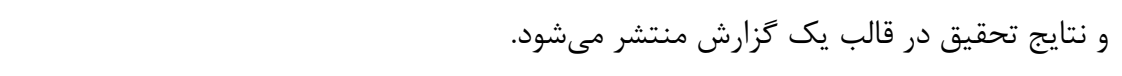

الف) اطلاعات جمعيت شناختى

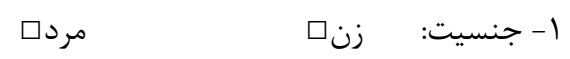

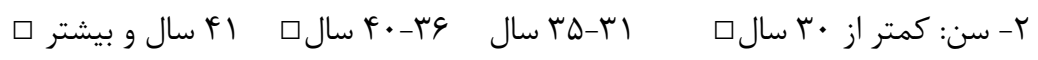

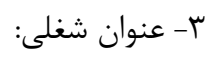

$$
\begin{aligned}
& \text { مديران واحدهاى حسابرسى داخلى ناشران بورسى و فرابورسى }
\end{aligned}
$$

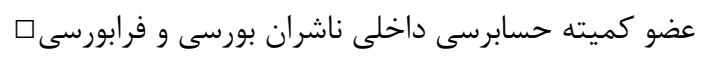

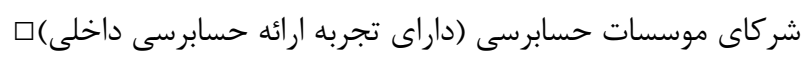

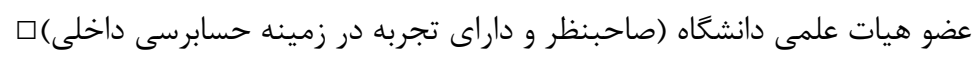

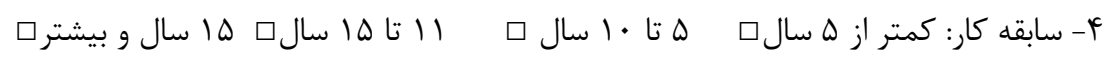

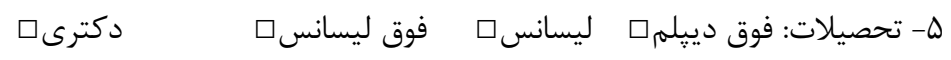

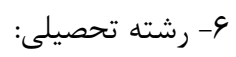

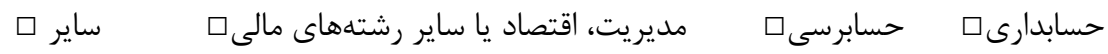

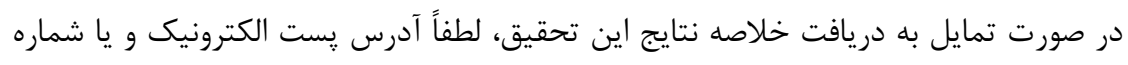

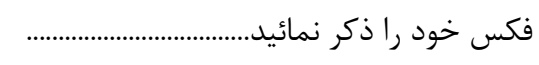

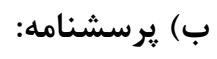


راهنماى تقسيم بندى شركتها بر اساس اندازه: شركتهاى بزرگ با متوسط فروش و دارايى

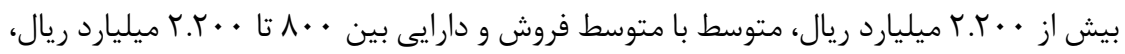
و كوجك با متوسط فروش و دارايى كمتر از · •1 ميليارد ريال در نظر كرفته شود.

\begin{tabular}{|c|c|c|c|c|c|c|}
\hline $\begin{array}{l}3 \\
y \\
y \\
z\end{array}$ & $v_{p}$ & $\begin{array}{l}3 \\
3 \\
3 \\
-7\end{array}$ & $\overrightarrow{0}$ & 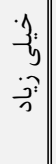 & 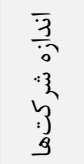 & ابعاد شايستگى \\
\hline & & & & & بزرى & \multirow{3}{*}{ 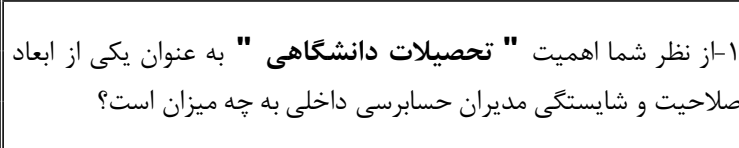 } \\
\hline & & & & & متوسط & \\
\hline & & & & & كو דֶא & \\
\hline & & & & & بزرى & \multirow{3}{*}{ 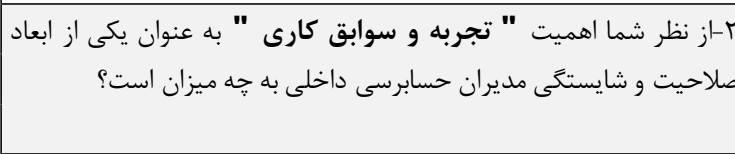 } \\
\hline & & & & & متوسط & \\
\hline & & & & & كوجك & \\
\hline & & & & & بزرى & \multirow{3}{*}{ 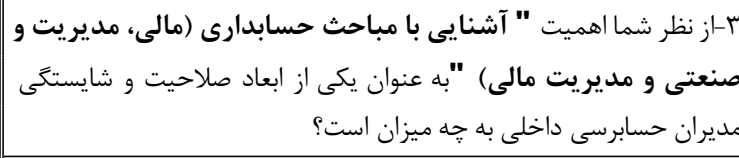 } \\
\hline & & & & & متوسط & \\
\hline & & & & & كوجك & \\
\hline & & & & & بزرى & \multirow{3}{*}{ 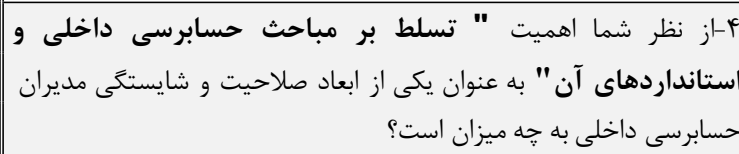 } \\
\hline & & & & & متوسط & \\
\hline & & & & & كو جָك & \\
\hline & & & & & بزرى & \multirow{3}{*}{ 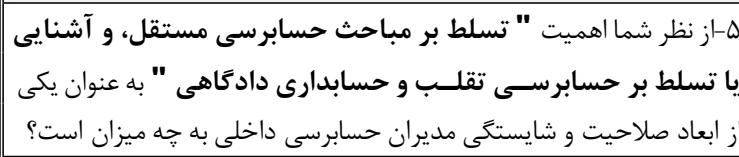 } \\
\hline & & & & & متوسط & \\
\hline & & & & & كوجك & \\
\hline & & & & & بزرى & \multirow{3}{*}{ 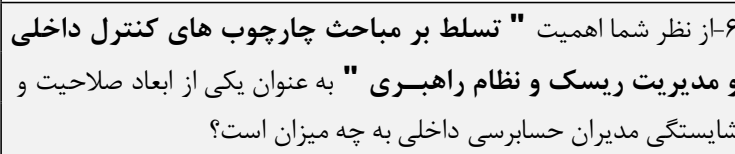 } \\
\hline & & & & & متوسط & \\
\hline & & & & & كوجك & \\
\hline & & & & & بزرى & \multirow{3}{*}{ 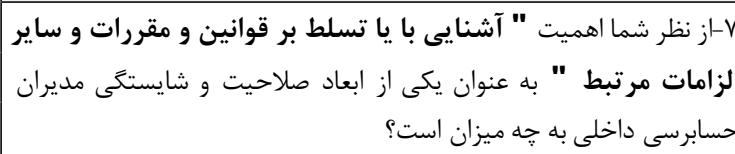 } \\
\hline & & & & & متوسط & \\
\hline & & & & & كوجك & \\
\hline & & & & & بزرى & \multirow{3}{*}{ 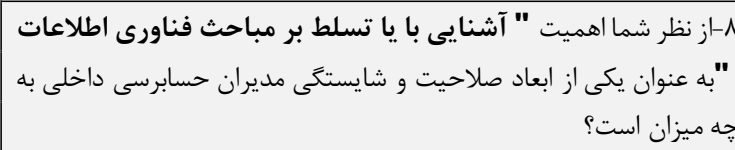 } \\
\hline & & & & & متوسط & \\
\hline & & & & & كو جك & \\
\hline & & & & & بزرى & \multirow{3}{*}{ 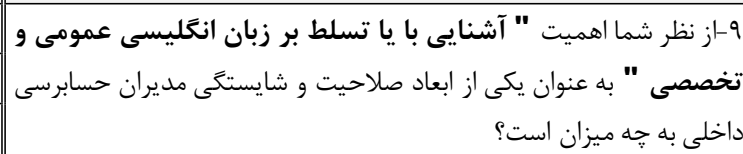 } \\
\hline & & & & & متوسط & \\
\hline & & & & & كو جָك & \\
\hline
\end{tabular}


rา1 دكتر وديعى و همكاران، طراحى مدل و اولويتبندى ابعاد شايستكى مديران حسابرسى داخلى...

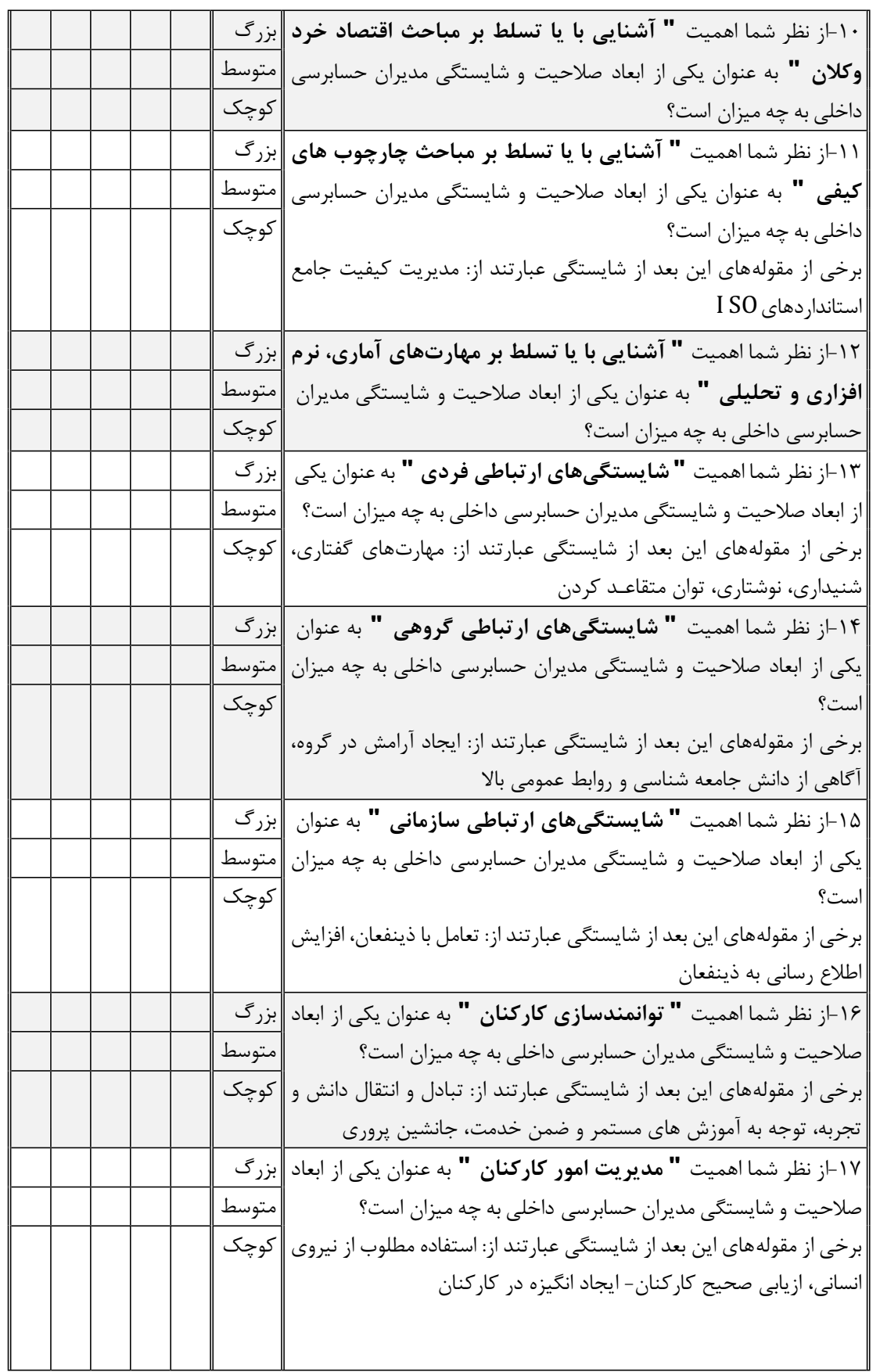




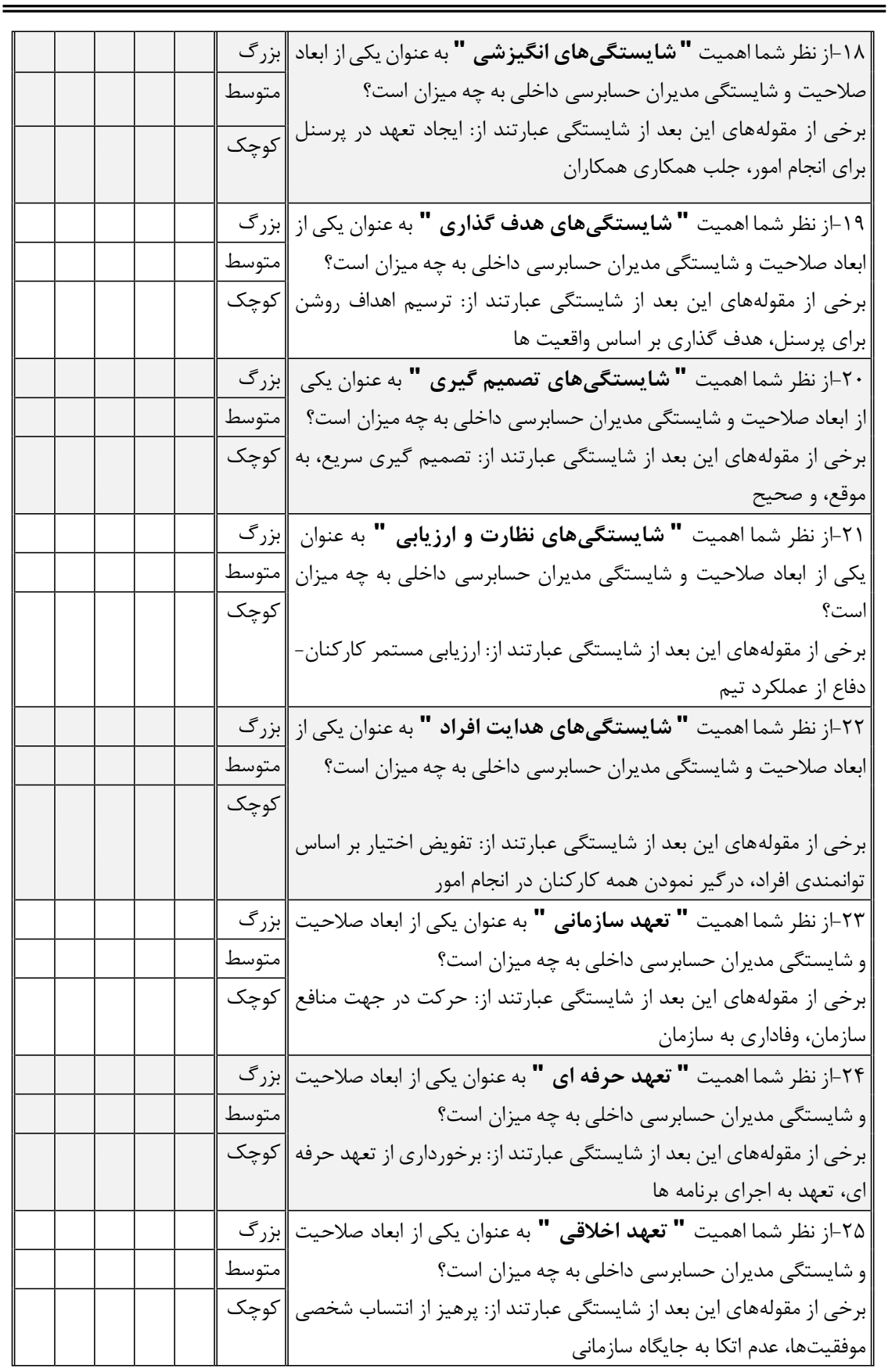




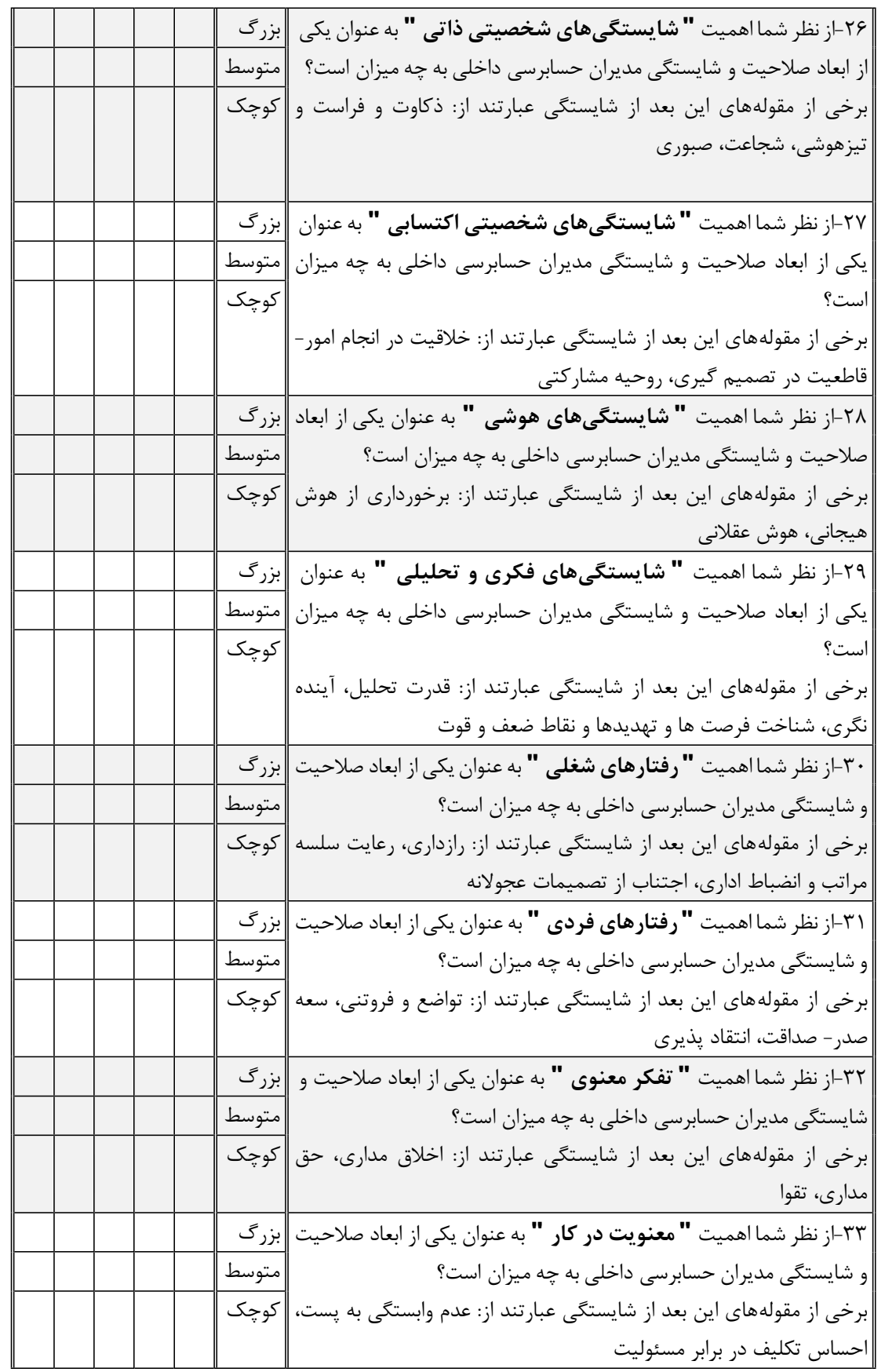




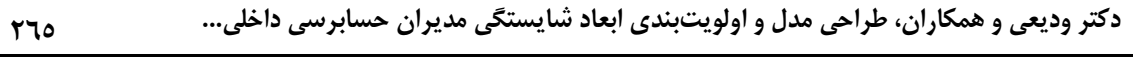

$$
\begin{aligned}
& \text { مشايخى، بيتا؛ حسن زاده، شادى؛ امينى، ياسين؛ منتى، وحيد.(هوس (1)، تأثير كيفيت حسابرسى } \\
& \text { داخلى بر حق الزحمه حسابرسى مستقل، يزوهشي، ئهاى حسابدارى مالى و و حسابرسى، }
\end{aligned}
$$

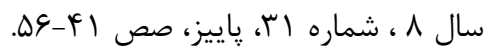

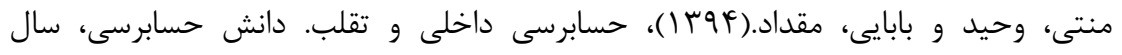

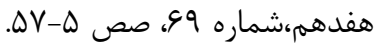

$$
\begin{aligned}
& \text { مهديلو تركمانى، ييمان؛ صفدرى رنجبر، مصطفى؛ مشبكى، اصغر؛ شجاعى، امير عباس (هو (I ). } \\
& \text { شناسايى و اولويتبندى شايستكى هاى مديران واحدهاى تحقيق و توسعه و فناورى، سال } \\
& \text { rا، شماره } 9 \text { I }
\end{aligned}
$$

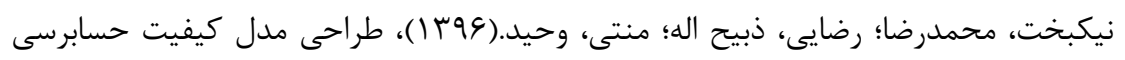

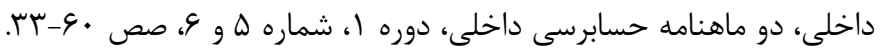

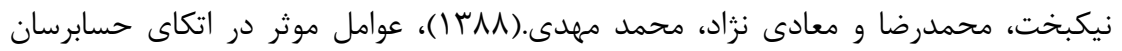

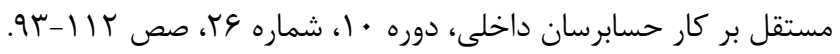

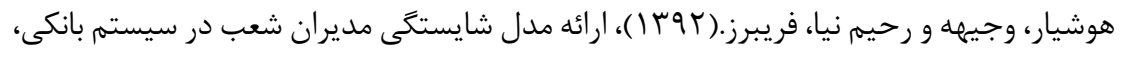

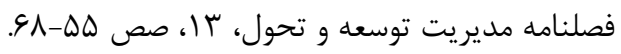

Abdolmohammadi, M., G. D’Onza, and G. Sarens. 2016. Benchmarking Internal Audit Maturity: A High-Level Look at Audit Planning \& Processes Worldwide, The Global Internal Audit Common Body of Knowledge, CBOK 2015 Practitioner Survey, the IIA research Foundation (IIARF), July.

Agut, S., R. Grau, and J.M. Peiro'. 2003. Competency needs among managers from Spanish hotels and restaurants and their training demands. International Journal of Hospitality Management, Vol.22,No. 3: 281-295.

Aitken, K., and K. Von Treuer. 2014. Organisational and leadership competencies for successful service integration. Leadership in Health Services, 27(2): 150180.

Badara, M.S., and S.Z. Sadin. 2013. The Journey so far on Internal Audit Effectiveness: a Calling for Expansion. international Journal of Academic Research in Accounting, Finance and Management Sciences, Vol. 3, No.3: 340-351.

BarclaySimpson, 2012. corporate governance recruitment market report 2012 internal audit. See more at: http://www.barclaysimpson.com/ document_ uploaded/BS2012_IntAuditMR.pdf.

Brown, L., B. George, and C. Mehaffey-Kultgen. 2018. The development of a competency model and its implementation in a power utility cooperative: an action research study. Industrial and Commercial Training, 50(3): 123-135.

Burton, F.G., M. Starliper, S.L. Summers, and D.A. Wood. 2012. Recruiting internal auditors: The effects of using the internal audit function as a management 
training ground and performing consulting services. Social Sciences Research Network.

Christ, M.H., A. Masli, N.Y. Sharp, and D.A. Wood. 2012. Using the internal audit function as a management training ground: Is the monitoring effectiveness of internal auditors compromised. SSRN Electronic Journal. https://doi. org/10.2139/ssrn, 1946518.

Cochran, G. 2009. Developing a Competency Model for a 21th Century Extension Organization, Ohio State University, a doctor of dissertation.

Corbin, J. M., and A. Strauss. 1990. Grounded theory research: Procedures, canons, and evaluative criteria. Qualitative sociology, 13(1): 3-21.

Creswell, J. 2005. Research Design: Qualitative and Quantitative Approaches, 2nd edition, Thousand Oaks, California.

Desai, N. K., G. J. Gerard, and A. Tripathy. 2011. Internal Audit Sourcing Arrangements and Reliance by External Auditors. Auditing: A Journal of Practice \& Theory 30 (1): 149-171.

Desai, R., V. Desai, T. Libby, and R.P. Srivastava. 2017. External auditors' evaluation of the internal audit function: An empirical investigation, International Journal of Accounting Information Systems, Volume 24, February: 114-124.

Dubois, D. D., W.J. Rothwell, D. J., Stern, and L.K. Kemp. 2004. Competency-based human resource management. Palo Alto, CA: Davies-Black Publishing.

Ege, M. S. 2013. Does internal audit function quality deter management misconduct? University Of Texas at Austin.

Ege, M.S. 2015. Does Internal Audit Function Quality Deter Management Misconduct? The Accounting Review, 90(2): 495-527.

Esser, A., Kahrens, M., Mouzughi, Y., \& Eomois, E. 2018. A female leadership competency framework from the perspective of male leaders. Gender in Management: An International Journal, 33(2): 138-166.

Gramling, A. A., M. J. Maletta, A. Schneider, and B. K. Church. 2004. The Role of the Internal Audit Function in Corporate Governance: A Synthesis of the Extant Internal Auditing Literature and Directions for Future Research. Journal of Accounting Literature 23:194-244.

Gros, M., and S. Koch. 2017. Internal audit function quality and financial reporting: results of a survey on German listed companies, Journal of Management \& Governance, June, Volume 21, Issue 2: 291-329.

Khalid, A. A., H. Haron, and T.A. Masron. 2018. Competency and effectiveness of internal Shariah audit in Islamic financial institutions. Journal of Islamic Accounting and Business Research, 9(2): 201-221.

Kregel, I., N. Ogonek, and B. Matthies. 2019. Competency profiles for lean professionals-an international perspective. International Journal of Productivity and Performance Management, 68(2): 423-446.

Lawler, E. E. 1994. From job-based to competency-based organizations. Journal of Organizational Behavior, Vol. 15, No.1: 3-15.

Lee, Y. 2010. Exploring high-performers' required competencies, Expert Systems with Applications, Vol. 37: 434-439. 
Lenz, R. 2013.Insights into the effectiveness of internal audit: a multi-method and multi-perspective study, dissertation at the Université catholique de Louvain - Louvain School of Management Research Institute.

Lin, S., M. Pizzini, M. Vargus, and I.R. Bardhan. 2011. The role of the internal audit function in the disclosure of material weaknesses. The Accounting Review, 86(1): 287-323.

Malaescu, I., and S.G. Sutton. 2015. The Reliance of External Auditors on Internal Audit's Use of Continuous Audit, Journal of Information Systems, Spring, Vol. 29, No. 1: 95-114.

Messier Jr, W.F., J.K. Reynolds, C.A. Simon, and D.A. Wood. 2011. The effect of using the internal audit function as a management training ground on the external auditor's reliance decision. The accounting review, 86(6): 2131-2154.

Meyer, M. A. 2019. Competencies required for healthcare improvement positions. International Journal of Health Care Quality Assurance.

Pizzini, M., S. Lin, and D.E. Ziegenfuss. 2015. The Impact of Internal Audit Function Quality and Contribution on Audit Delay, A Journal of Practice \& Theory, February 2015, Vol. 34, No. 1: 25-58.

Prawitt, D.F., J.L. Smith, and D.A. Wood. 2009. Internal audit quality and earnings management. The accounting review, 84(4):1255-1280.

Seol, I., J. Sarkis, and F. Lefley. 2011. Factor structure of the competency framework for internal auditing (CFIA) skills for entering level internal auditors. International Journal of Auditing, 15(3): 217-230.

Strauss, A., \& J.M. Corbin. 1990. Basics of qualitative research: Grounded theory procedures and techniques. Sage Publications, Inc.

Tehseen, S., F.U. Ahmed, Z.H. Qureshi, and M.J. Uddin. 2019. Entrepreneurial competencies and SMEs' growth: the mediating role of network competence. Asia-Pacific Journal of Business Administration, 11(1): 2-29.

The Institute of Internal Auditors (IIA). 2011. Recruitment Strategies for Tomorrow's Internal.

Trivellas, P., and C. Drimoussis. 2013. Investigating Leadership Styles, Behavioural and Managerial Competency Profiles of Successful Project Managers in Greece, Social and Behavioral Sciences,vol. 73: 692 - 700

Uhbiyati, N. 2015. A competency-based model of the human resource development management of ustadz at salaf boarding school. International Journal of Educational Management, 29(5): 695-708.

Viitala, R. 2005. Perceived development needs of managers compared to an integrated management competency model, Journal of Workplace Learning. 17(8): 436-442.

Weatherly, L. A. 2005. Competency models series part I: Competency models - an overview. Available from Society for Human Resource Management: http://shrm.org

Wu, T. H., S.M. Huang, S.Y. Huang, and D.C. Yen. 2016. The effect of competencies, team problem-solving ability, and computer audit activity on internal audit performance. Information Systems Frontiers: 1-16. 